\title{
Carbon Peak and Carbon Neutrality in the Building Sector: A Bibliometric Review
}

\author{
Zhaohui Sun ${ }^{1}$, Zhili Ma ${ }^{1, *}$, Minda Ma ${ }^{2,3,4, * \mathbb{D}}$, Weiguang Cai ${ }^{1}$, Xiwang Xiang ${ }^{1}$, Shufan Zhang ${ }^{1}$, Minxia Chen ${ }^{1}$ \\ and Liming Chen ${ }^{1}$
}

1 School of Management Science and Real Estate, Chongqing University, Chongqing 400045, China; zhaohuisun@cqu.edu.cn (Z.S.); cquwgcai@gmail.com (W.C.); xiangxiwang@cqu.edu.cn (X.X.); zhangshufan@cqu.edu.cn (S.Z.); chenminxia@cqu.edu.cn (M.C.); chenliming@cqu.edu.cn (L.C.)

2 School of Architecture and Urban Planning, Chongqing University, Chongqing 400045, China

3 Key Laboratory of New Technology for Construction of Cities in Mountain Area, Ministry of Education, Chongqing University, Chongqing 400045, China

4 Department of Earth System Science, Tsinghua University, Beijing 100084, China

* Correspondence: mzlmx@cqu.edu.cn (Z.M.); maminda@cqu.edu.cn (M.M.)

check for updates

Citation: Sun, Z.; Ma, Z.; Ma, M.; Cai, W.; Xiang, X.; Zhang, S.; Chen, M.; Chen, L. Carbon Peak and Carbon Neutrality in the Building Sector: A Bibliometric Review. Buildings 2022, 12, 128. https://doi.org/10.3390/ buildings 12020128

Academic Editor: Srinath Perera

Received: 14 December 2021

Accepted: 23 January 2022

Published: 26 January 2022

Publisher's Note: MDPI stays neutral with regard to jurisdictional claims in published maps and institutional affiliations.

Copyright: () 2022 by the authors. Licensee MDPI, Basel, Switzerland. This article is an open access article distributed under the terms and conditions of the Creative Commons Attribution (CC BY) license (https:// creativecommons.org/licenses/by/ $4.0 /)$.

\begin{abstract}
Due to large energy consumption and carbon emissions (ECCE) in the building sector, there is huge potential for carbon emission reduction, and this will strongly influence peak carbon emissions and carbon neutrality in the future. To get a better sense of the current research situation and future trends and to provide a valuable reference and guidance for subsequent research, this study presents a summary of carbon peak and carbon neutrality $(\mathrm{CPCN})$ in buildings using a bibliometric approach. Three areas are addressed in the review through the analysis of 364 articles published from 1990-2021: (1) Which countries, institutions, and individuals have conducted extensive and in-depth research on CPCN in buildings, and what is the status quo of their collaboration and contributions? (2) What subjects and topics have aroused wide interest and enthusiasm among scholars, and what are their time trajectories? (3) What journals and authors have grabbed the attention of many scholars, and what are the research directions related to them? Moreover, we propose future research directions. Filling these gaps will enrich the research body of CPCN and overcome current limitations by developing more methods and exploring other practical applications.
\end{abstract}

Keywords: building energy; carbon peak; carbon neutrality; bibliometric study

\section{Introduction}

The building and construction industries, as well as the policies and standards promulgated therein, not only affect social and economic development [1], but are also closely related to environmental protection [2,3]. When it meets people's needs through buildings [4], it will inevitably impact the environment throughout the entire lifecycle of a building [5]. The building sector, one of the three major sectors in terms of energy consumption (i.e., industry, transportation, construction) and one of the main areas of responsibility for direct and indirect carbon emissions, accounted for $36 \%$ of the final energy consumption and $38 \%$ of the total carbon emissions in 2019 [6]. With the development of cities and rapid economic growth worldwide, the rapid growth of energy consumption and carbon emissions (ECCE) in the building sector has attracted more and more attention from countries around the world [7-11]. Due to the huge ECCE of the building sector, the carbon emission abatement potential of the construction industry will significantly influence the carbon peak and carbon neutrality (CPCN) in the future [12], aroused great attention from academics and industry practitioners.

The existence of a carbon emissions peak means that there will be a steady decline in carbon emissions after reaching a plateau [13]. Carbon neutrality refers to the total amount of greenhouse gas emissions produced by an enterprise, organization, or individual 
within a certain amount of time and the realization of a zero-carbon emissions status by offsetting these carbon emissions through forest planting, energy saving, and emission reduction $[14,15]$. Developed countries and major economies have developed their own targets to curb greenhouse gas emissions and are trying to do their part [16-20]. For example, China, a major emitter of greenhouse gases, has made a commitment to reach its carbon emissions peak by 2030 and to achieve a carbon neutral status by 2060 [21]. The United States aims to decrease its carbon dioxide emissions by $17 \%$ by 2020 and by $83 \%$ by 2050 compared with 2005 levels [22]. The UK has set the objective of cutting greenhouse gas emissions by at least $20 \%$ by 2050 compared with 1990 levels [23].

From 1990 to 2021, research on CPCN in the building sector was diverse and active. Since the CPCN of the building sector should be considered from the perspective of the lifecycle, research in this area either covers a single phase (design, construction, and operation) or the entire lifecycle. For example, You et al. calculated the overall carbon dioxide emissions of residential buildings through their lifecycles [24]. Zhang et al. discussed the trends in ECCE in China's building sector from 2000 to 2016 using the China Building Construction Model based on the life cycle assessment method [25]. Danatzko et al. analyzed energy use by structural parts made up of different materials throughout the life cycle to achieve sustainable design [26]. Sozer et al. changed the building envelope during the design phase to improve energy efficiency [27]. Lam et al. revealed that the participation of stakeholders impacts other factors through the implementation of green codes in the construction phase [28]. Chen et al. investigated the changes in carbon emissions on different emission scales during the operation phase of civil buildings from 30 provinces of China [29]. Research on CENCN in buildings can also focus on commercial buildings and residential buildings [30,31]. For example, Ma et al. measured carbon emission abatement in commercial buildings in China based on the Kaya-LMDI method [32,33]. Hong et al. studied the energy efficiency of small commercial buildings using an energy analysis tool [34]. Zhang et al. analyzed the road map of carbon neutrality in the operation stage of commercial buildings and made a comparison between China and the United States [35,36]. Tian et al. investigated the status quo of near (net) zero-energy residential buildings in Beijing [37]. Zheng, Wei, and Wang et al. conducted a household survey on the energy consumption characteristics of Chinese residents [38]. In addition to the CPCN study on urban buildings, Yao et al. and Zhang et al. analyzed the reduction of ECCE in rural buildings and found that the energy use of rural residents has significantly shifted from non-commercial energy to commercial energy [39,40].

In the existing literature, there are various reviews on the research of $\mathrm{CPCN}$ in buildings, but these tend to focus on a limited part of the method [41-44], technologies [45-50], or on the macro research subjects of systems and laws [8,51-56]. For instance, Ali and Xiao reviewed the method for estimating building embodied carbon and the strategy for reducing it [57]; Ma, Cai, and Wu reviewed the implementation of the China Act on the Energy Efficiency of Civil Buildings (2008) over the past decade [58]. Chau et al. reviewed the research progress on the assessment of energy and carbon emissions during a building's lifecycle [59]. However, to the best of our knowledge, few studies have outlined the research trend and cooperation network for $\mathrm{CPCN}$ in the building sector, and most review articles have determined research topics from a subjective point of view. To get a better sense of the current research situation and future trends and to provide a valuable reference and guidance for subsequent research, we needed to address three problems.

- Which countries, institutions, and individuals have conducted extensive and in-depth research on CPCN in buildings, and what is the status quo of their cooperation and contributions?

- What subjects and topics have aroused wide interest and enthusiasm among scholars, and what are their time trajectories?

- What journals and authors have grabbed the attention of many scholars, and what are the research directions related to them? 
Bibliometrics can be used to observe the state of technology and science during the overall production of scientific literature [60], and citation analysis is a common method used in bibliometrics to visualize the results of the analysis and map knowledge fields, so as to master the research frontiers hidden in the literature knowledge [5]. The research results presented in this article summarize the current situation in this area of research, identify the hot spots and knowledge gaps in the literature, and indicate potential future research directions.

The rest of the paper is presented as follows: Section 2 contains the data retrieved and describes the data processing methods used. Section 3 is the main part of this paper. Section 3.1 explains the changes in the number of annual publications for the top ten countries and the trend for the cumulative number of publications. Section 3.2 contains three parts, presented in Sections 3.2.1-3.2.3: the cooperative relationships and contributions of the authors, research institutions, and countries are analyzed. Section 3.3 describes the disciplines and topics related to CPCN in buildings. This section consists of Section 3.3.1 (subject category co-occurrence network) and Section 3.3.2 (keywords co-occurrence analysis). The last part (i.e., Section 3.4) of Section 3, which describes the intellectual structure of CPCN in buildings, is also subdivided into three parts, Section 3.4.1, Section 3.4.2, and Section 3.4.3, which present a co-citation analysis of journals, documents, and author. Section 4 discusses the current research gaps and future research. Section 5 presents the conclusions.

\section{Materials and Methods}

\subsection{Data Retrieved}

Through a comparative analysis of the statistics retrieved from the Scopus and Web of Science (WOS) databases, it was determined that the articles and references retrieved by these two databases were highly similar [61]. Since the core set of WOS databases contains high-quality data, groundbreaking content, and a longer history than Scopus, we chose the 'Science Citation Index Expanded (SCI-EXPANDED)' and 'Social Sciences Citation Index (SSCI)' of the core set of WOS databases to retrieve the data originally used for analysis [62]. Since journal articles usually provide deeper research and higher quality information than other types of publications [5], the literature types chosen were research articles and review articles. The language was set as English. The time period of the articles was set to 1990-2021, as the focus of this research was on the development of this topic following the adoption of the United Nations Framework Convention on Climate Change in 1992. We expected our data to reveal the trends that have emerged in the past 30 years.

The input data we reviewed were generated from a combination of the results of multiple subject search queries on WOS (Table 1). First, literature in research fields and topics was retrieved through different retrieval queries, and the results are shown as Set \#1-Set \#5 in Table 1. According to the WOS database retrieval rules, '*' and 'TS' stand for fuzzy search and publication article topics, respectively. Then, through the Boolean operation "And" operation symbol to locate the four topics to the research field, the results Set \#6-Set \#9 were obtained. The amount of literature in Set \#6 and Set \#7 shows that many scholars have conducted studies on ECCE in the field of buildings. Based on the research on ECCE in the building sector, this review focused on the research topic of CPCN in buildings, so finally, Set \#8 and Set \#9 were combined by the "OR" operation symbol. Hence, a list of 364 publication records was gathered for the review analysis, including 328 research articles and 36 review papers. Each record consisted of the author, affiliate, country/region, year of publication, source journal, title, abstract, keywords, and references. 
Table 1. Topic search queries used for data collection.

\begin{tabular}{|c|c|c|c|c|c|}
\hline Set & Search Queries & Time Span & Publications & Articles & Reviews \\
\hline$\# 1$ & $\mathrm{TS}=$ (building OR construction) & 1990-2021 & $1,198,060$ & $1,142,270$ & 55,790 \\
\hline \#2 & $\begin{aligned} \mathrm{TS}= & (\text { "energy consumption *" OR “energy } \\
& \text { demand *" OR “energy use *") }\end{aligned}$ & 1990-2021 & 116,712 & 109,202 & 7510 \\
\hline \#3 & $\mathrm{TS}=\left(\right.$ "carbon emission *" $\mathrm{OR}$ “ $\mathrm{CO}_{2}$ emission *" $)$ & 1990-2021 & 48,553 & 45,656 & 2897 \\
\hline$\# 4$ & 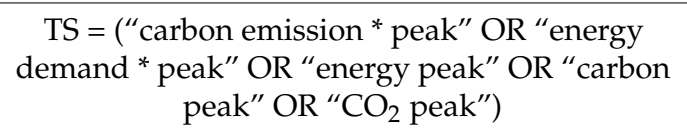 & 1990-2021 & 2014 & 1995 & 19 \\
\hline \#5 & $\begin{array}{c}\text { TS = (“carbon neutrality" OR “carbon neutral” } \\
\text { OR "net zero emission" OR "nearly zero } \\
\text { emission") }\end{array}$ & 1990-2021 & 2150 & 1793 & 357 \\
\hline \#6 & \#2 AND \#1 & 1990-2021 & 22,949 & 21,433 & 1516 \\
\hline$\# 7$ & \#3 AND \#1 & 1990-2021 & 7042 & 6522 & 520 \\
\hline$\# 8$ & \#4 AND \#1 & 1990-2021 & 100 & 99 & 1 \\
\hline \#9 & \#5 AND \#1 & 1990-2021 & 270 & 235 & 35 \\
\hline$\# 10$ & \#9 OR \#8 & 1990-2021 & 364 & 328 & 36 \\
\hline
\end{tabular}

\subsection{Data Processing Methods}

In the Bibliometrics field, different types of knowledge mapping software (Publish or Perish, CiteSpace, VOSviewer, HistCite, and BibExcel, etc.) have different features and limitations [63]. Since VOSviewer (version 1.6.16, Nees Jan van Eck and Ludo Waltman, Leiden University, Leiden, Netherlands). performs well in the visualization of contributions and cooperation, it was used to analyze the contributions and cooperation of institutions and authors. At the same time, CiteSpace software can be used to carry out co-occurrence and co-citation analyses and can be used to visualize the knowledge field of bibliographic records [64]. Thus, it can be used to analyze the co-occurrence of keywords and subjects as well as the co-citation of journals, documents, and authors. It is worth noting that compared with manual reviews, bibliometric reviews can draw more objective conclusions by examining the quantitative and unbiased links between different studies. They can supplement manual reviews but cannot replace them [65].

\section{Results}

\subsection{The Publication Trends}

The annual distribution of $\mathrm{CPCN}$ in the building sector reflects the development speed and knowledge accumulation status of this field [63]. According to the data in Set \#10 retrieved from the "Web of Science Core Collection", and as shown in Figure 1, the annual publication volume has increased year-by-year. Initially, steady growth began in 2005 through publications from England and Australia. Publications began to increase rapidly in 2015, indicating that the Paris Agreement for energy saving and emission reduction policies in various countries around the world had a significant impact and caused experts and scholars in various countries to conduct research in the field of CPCN in buildings [66-68]. In 2020, the growth rate of literature publishing accelerated significantly in line with the occurrence of the 2020 Climate Ambition Summit initiated by the United Nations and relevant countries to commemorate the fifth anniversary of the Paris Agreement. It is clear that the 2020 Climate Ambition Summit further mobilized the international community to strengthen climate action and advance the multilateral process [69]. 


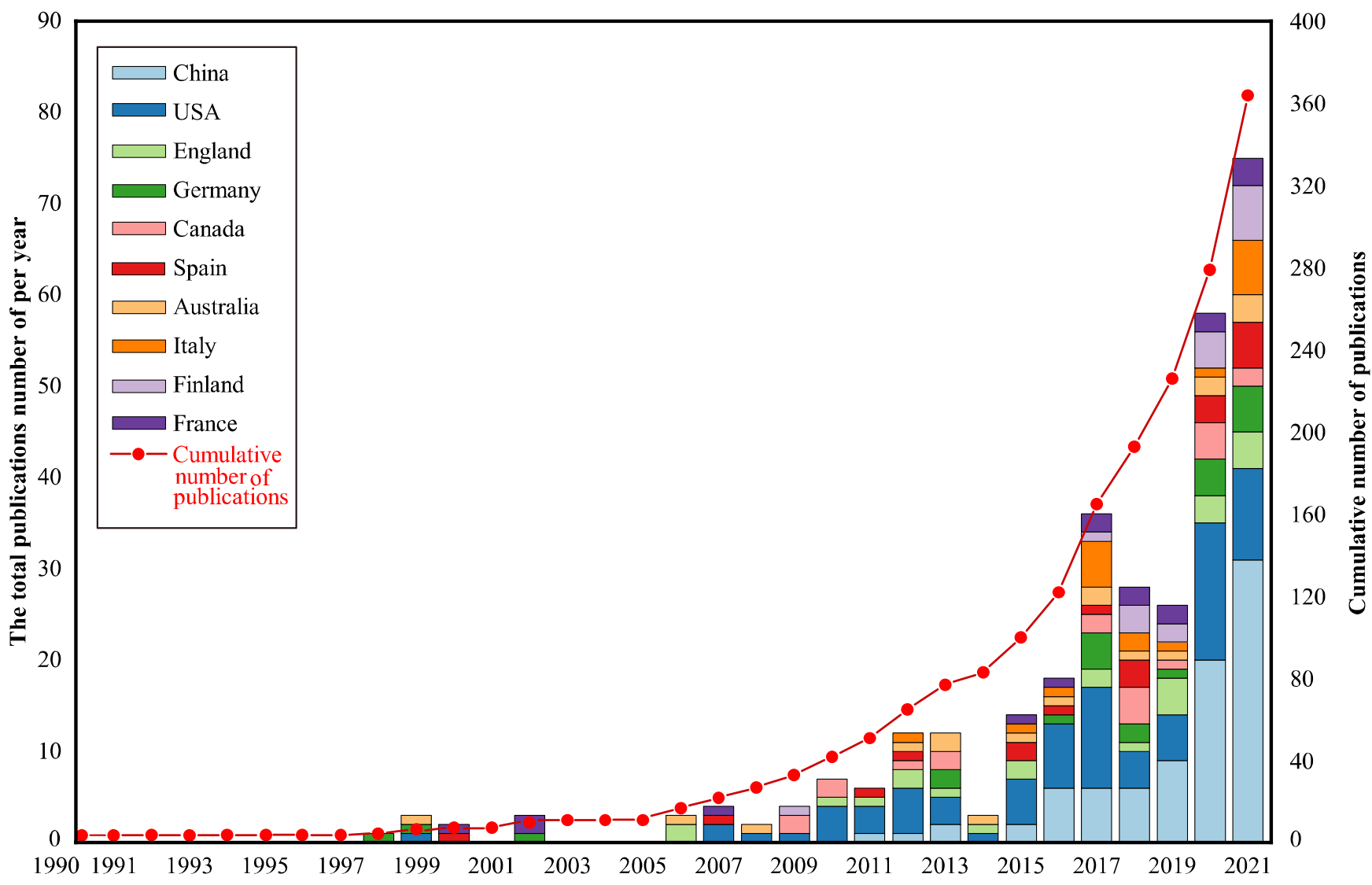

Figure 1. Annual change curves for articles published in the field of CPCN in buildings (1990-2021).

Figure 1 also shows the annual publication changes for the top ten countries. What is noteworthy in terms of publication volume is that among the top 10 countries the only developing country is China, while the rest are all developed countries. However, global sustainable development needs joint effort from all countries, so this means that developing countries need to conduct more cooperative research with developed countries, and developed countries should provide more help to developing countries. Publications from China have maintained rapid growth, especially in 2016. This trend is also consistent with the development of the "Thirteenth Five-Year Plan for Controlling Greenhouse Gas Emissions" issued by the State Council of China in 2016 [70,71]. Publications on CPCN in buildings from the USA, England, Italy, Germany, Canada, France, Australia, India, and Spain have generally shown an upward trend. In addition, the cumulative number of publications has increased exponentially.

\subsection{Contributions and Cooperation from Three Aspects: Author, Institution, and Country}

\subsubsection{Author Contributions and Collaboration}

The analysis of the author's cooperation and contributions to the CPCN in the building sector can provide some guidance for scholars seeking cooperation in similar fields. Table 2 lists the top 10 authors who have published the most articles in the field of CPCN in buildings. We can see that the number of articles published by authors in this field is relatively small. Prof. Cai Weiguang from Chongqing University has published six articles in this field and ranks first both in terms of the number of papers and the total number of citations. He is followed by Ma Minda from Tsinghua University, who has published four papers on the subject and is ranked first in citations per paper. It is worth noting that the first, second, fifth, and seventh authors in the top 10 are from China, two are from Australia, and two are from Finland. 
Table 2. Top 15 authors with the most publications on CPCN in buildings.

\begin{tabular}{|c|c|c|c|c|c|c|c|}
\hline Rank & Author & Country & Organization & Documents & Citations & TLS $^{a}$ & $\mathrm{CPP}{ }^{b}$ \\
\hline 1 & Cai, Weiguang & China & Chongqing University & 6 & 267 & 17 & 44.50 \\
\hline 2 & Ma, Minda & China & Tsinghua University & 4 & 262 & 8 & 65.50 \\
\hline 3 & Pullen, Stephen & Australia & University of South Australia & 3 & 99 & 8 & 33.00 \\
\hline 4 & Junnila, Seppo & Finland & Aalto University & 3 & 13 & 10 & 4.33 \\
\hline 5 & Cai, Wei & China & Southwest University & 2 & 121 & 6 & 60.50 \\
\hline 6 & Bogdanov, Dmitrii & Finland & $\begin{array}{c}\text { Lappeenranta University } \\
\text { of Technology }\end{array}$ & 2 & 120 & 11 & 60.00 \\
\hline 7 & Dong, Liang & China & City University of Hong Kong & 2 & 113 & 10 & 56.50 \\
\hline 8 & Meil, Jamie & Canada & $\begin{array}{l}\text { Athena Sustainable Materials } \\
\text { Institute }\end{array}$ & 2 & 106 & 3 & 53.00 \\
\hline 9 & Zuo, Jian & Australia & The University of Adelaide & 2 & 75 & 11 & 37.50 \\
\hline 10 & Georges, Laurent & Norway & $\begin{array}{c}\text { Norwegian University of Science } \\
\text { and Technology }\end{array}$ & 2 & 75 & 11 & 37.50 \\
\hline
\end{tabular}

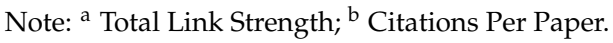

The total link strength (TLS), analyzed with the VOSviewer software, reveals the frequency of cooperation between cooperating authors, institutions, and countries based on available publications. The TLS shown in Table 2 indicates preliminary cooperation among scholars, but the frequency of cooperation is relatively low. This also can be observed in Figure 2.

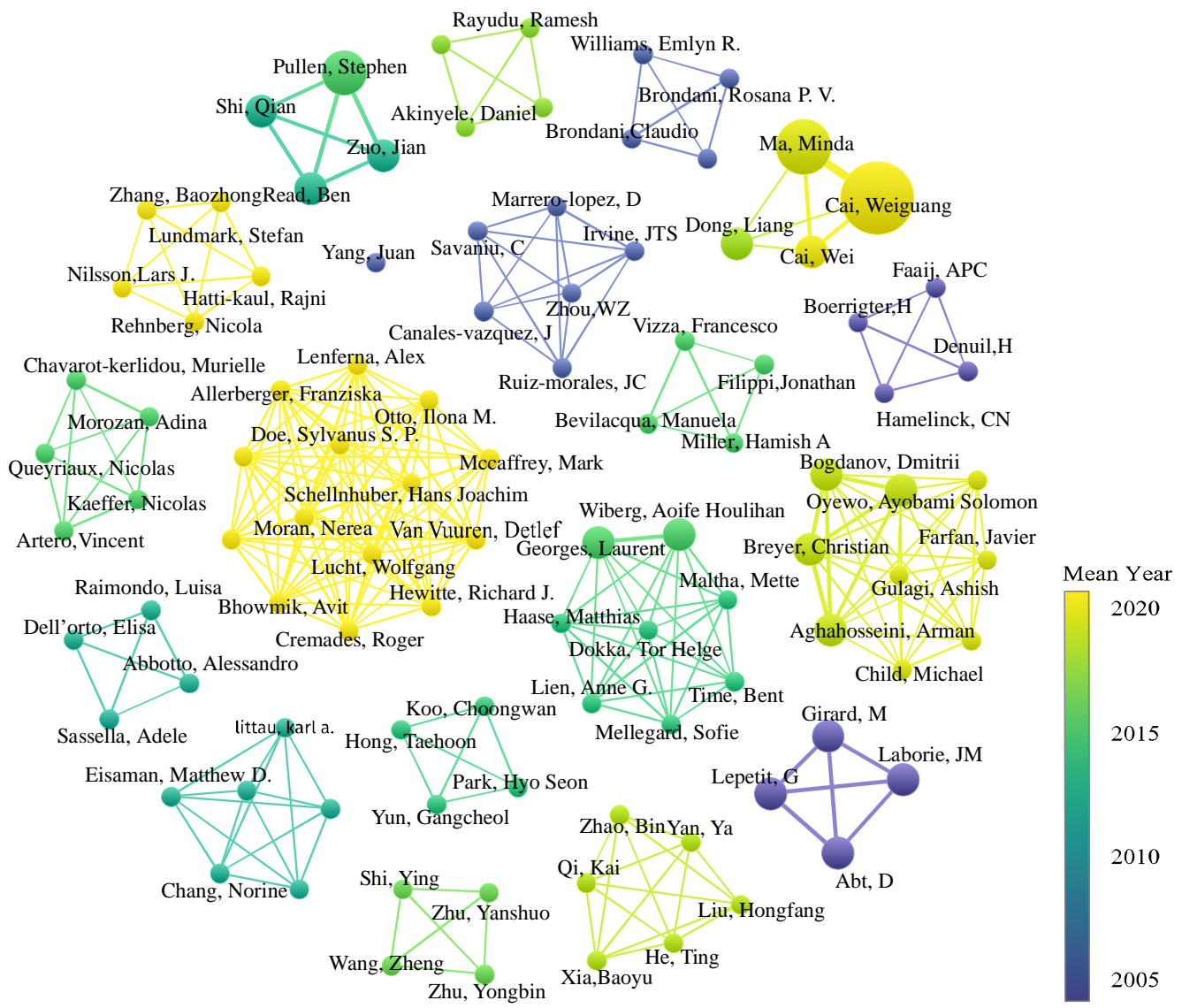

Figure 2. Overlay visualization map of co-authors.

VOSviewer software was used to carry out overlay visual mapping for the TLS of the top 100 authors. In Figure 2, the node size represents the number of co-authored articles. The links between nodes represent collaboration, and a larger link width indicates closer collaboration between authors [63]. In Figure 2, we can see the contribution and cooperation 
degrees of experts more intuitively than in Table 2. Different nodes come together to form a cluster, with frequent cooperation within a cluster but less cooperation between clusters.

Different node colors in the figure represent the different average publication times for an author's articles. The warmer the node color, the closer the publication time of the author's article. This indicates whether an author is currently active in this research field, with active authors including Prof. Cai Weiguang and Cai Wei. On the contrary, the colder the node, the longer the publication time of the author's article. A cold node indicates that the authors have done preliminary basic research for the development of this field, for example, Prof. Girard M., Laborie J.M., Lepetit G., and Abt, D.

\subsubsection{The Most Influential and Productive Institutions}

Table 3 lists the top 15 research institutions in terms of the number of articles published. Chongqing University ranks first for the total number of published articles and the total number of citations, with the number of published articles accounting for $2.20 \%$ of the total number. The Chinese Academy of Sciences has also published eight articles, while the National University of Singapore and the Aalto University have published seven articles each. It is worth noting that in terms of the average number of citations, the University of Washington ranks first with 47 citations per article.

Table 3. Top 15 institutions with the most publications on $\mathrm{CPCN}$ in buildings.

\begin{tabular}{|c|c|c|c|c|c|c|c|}
\hline Rank & Institution & Country & Publications & Percentage & Citations & TLS $^{a}$ & $\mathrm{CPP}{ }^{b}$ \\
\hline 1 & Chongqing University & China & 8 & $2.20 \%$ & 308 & 15 & 38.50 \\
\hline 2 & Chinese Academy of Sciences & China & 8 & $2.20 \%$ & 137 & 13 & 17.13 \\
\hline 3 & National University of Singapore & Singapore & 7 & $1.92 \%$ & 61 & 5 & 8.71 \\
\hline 4 & Aalto University & Finland & 7 & $1.92 \%$ & 19 & 0 & 2.71 \\
\hline 5 & Tsinghua University & China & 6 & $1.65 \%$ & 162 & 24 & 27.00 \\
\hline 6 & $\begin{array}{l}\text { Lawrence Berkeley } \\
\text { National Laboratory }\end{array}$ & USA & 5 & $1.37 \%$ & 178 & 21 & 35.60 \\
\hline 7 & The Hong Kong Polytechnic University & China & 5 & $1.37 \%$ & 130 & 7 & 26.00 \\
\hline 8 & Southeast University & China & 5 & $1.37 \%$ & 44 & 5 & 8.80 \\
\hline 9 & North China Electric Power University & China & 5 & $1.37 \%$ & 14 & 0 & 2.80 \\
\hline 10 & University of Washington & USA & 4 & $1.10 \%$ & 188 & 20 & 47.00 \\
\hline 11 & Stockholm University & Sweden & 4 & $1.10 \%$ & 92 & 20 & 23.00 \\
\hline 12 & $\begin{array}{l}\text { National Institute for } \\
\text { Environmental Studies }\end{array}$ & Japan & 4 & $1.10 \%$ & 89 & 9 & 22.25 \\
\hline 13 & Swiss Federal Institute of Technology & Switzerland & 4 & $1.10 \%$ & 71 & 3 & 17.75 \\
\hline 14 & The University of Tennessee & USA & 4 & $1.10 \%$ & 61 & 12 & 15.25 \\
\hline 15 & The University of Michigan & USA & 4 & $1.10 \%$ & 54 & 6 & 13.50 \\
\hline
\end{tabular}

Note: ${ }^{\text {a }}$ Total Link Strength; ${ }^{\mathrm{b}}$ Citations Per Paper.

Figure 3 shows the number of articles published by institutions and the partnerships between institutions. Each circular node represents a research institution, and the node size represents the number of articles issued by the institution. The links between nodes represent cooperation. The wider the link width, the closer the cooperation between institutions [63]. Different colors indicate different clusters of institution cooperation. Nodes of the same color belong to the same cluster, which means that the kinship between these nodes is stronger. In Figure 3, there are seven clusters altogether. Although Cluster \#5 has only three main items, Tsinghua University has the highest total link strength. Lawrence Berkeley National Laboratory follows Tsinghua University with a total link strength of 21, and it is shown to cooperate relatively frequently with Chongqing University and the Chinese Academy of Sciences. 


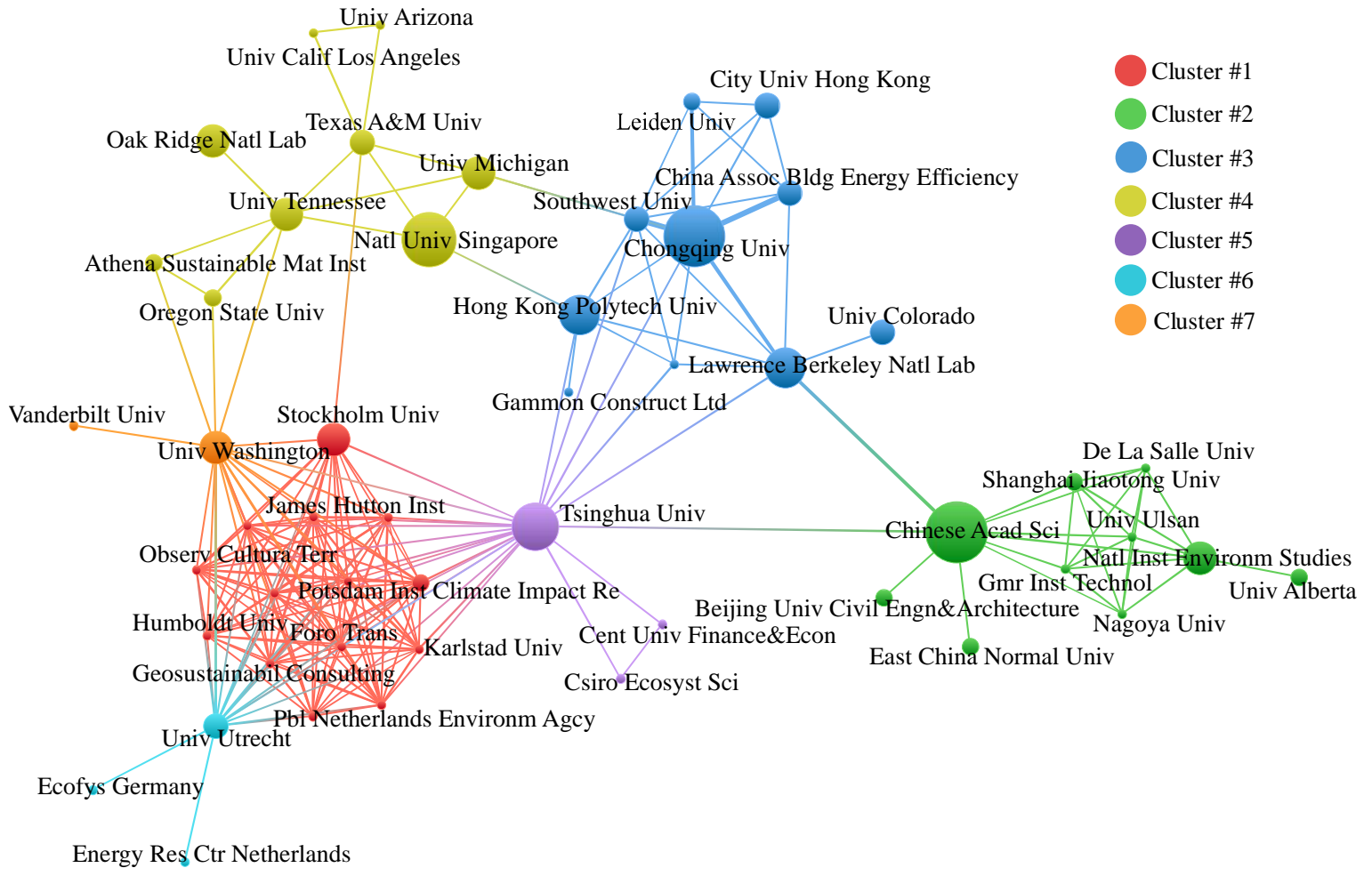

Figure 3. Knowledge domain map of institutional contributions and collaboration.

\subsubsection{The Most Influential and Productive Countries}

Table 4 lists the 20 countries with the most published articles. The numbers of articles published and of citations are significantly higher in China and the USA than in other countries. Similarly, China and the United States are also in the top two in terms of total link strength, indicating that both countries are actively engaged in collaborative research with other countries.

Table 4. Top 20 countries with the most publications on CPCN in buildings.

\begin{tabular}{|c|c|c|c|c|c|c|c|}
\hline No. & Country & Start Year & Publications & Centrality & Citations & Citations Per Paper & Total Link Strength \\
\hline 1 & China & 2011 & 84 & 0.05 & 1656 & 19.71 & 48 \\
\hline 2 & USA & 1999 & 77 & 0.27 & 1401 & 18.19 & 53 \\
\hline 3 & England & 2006 & 24 & 0.16 & 745 & 31.04 & 15 \\
\hline 4 & Germany & 1998 & 22 & 0.43 & 760 & 34.55 & 30 \\
\hline 5 & Canada & 2009 & 20 & 0.12 & 534 & 26.70 & 9 \\
\hline 6 & Spain & 2000 & 19 & 0.58 & 193 & 10.16 & 22 \\
\hline 7 & Australia & 1999 & 18 & 0.3 & 424 & 23.56 & 13 \\
\hline 8 & Italy & 2012 & 18 & 0.05 & 312 & 17.33 & 16 \\
\hline 9 & France & 2000 & 17 & 0.05 & 291 & 17.12 & 17 \\
\hline 10 & Finland & 2009 & 17 & 0.11 & 189 & 11.12 & 8 \\
\hline 11 & Netherlands & 2004 & 12 & 0 & 669 & 55.75 & 16 \\
\hline 12 & Japan & 1993 & 12 & 0.05 & 139 & 11.58 & 7 \\
\hline 13 & Sweden & 2001 & 11 & 0 & 183 & 16.64 & 18 \\
\hline 14 & India & 2010 & 10 & 0.16 & 255 & 25.50 & 8 \\
\hline 15 & Scotland & 2006 & 9 & 0.6 & 477 & 53.00 & 15 \\
\hline 16 & Norway & 2009 & 8 & 0 & 180 & 22.50 & 3 \\
\hline 17 & $\begin{array}{l}\text { South } \\
\text { Korea }\end{array}$ & 2014 & 8 & 0.05 & 132 & 16.50 & 11 \\
\hline 18 & Belgium & 2002 & 8 & 0.11 & 97 & 12.13 & 10 \\
\hline 19 & Switzerland & 2017 & 8 & 0 & 93 & 11.63 & 12 \\
\hline 20 & Singapore & 2010 & 7 & 0 & 61 & 8.71 & 5 \\
\hline
\end{tabular}


Each individual knowledge network is composed of publications produced over a period of time, which is called a time slice. These independent networks were integrated by CiteSpace to form an overview to express how the field of science has evolved over time [72]. In Figure 4, the corresponding 3-year slice, 1990-2021, shows the networks of the 100 countries with the most publications. CiteSpace describes the changing trends and patterns that are emerging in such networks using various visual attributes [72]. In Figure 4, the node size represents the number of articles produced by a country. The number of articles published in the time slice of each country is described by the citation tree ring: the thicker the citation tree-ring, the greater the number of articles published in that time period. The structural attributes of the nodes are represented by purple rings. The thickness of the purple ring indicates its degree of betweenness centrality (BC). BC is a measure related to the transformational potential of scientific contributions. Nodes with a purple ring often connect different phases of the development of a scientific field.

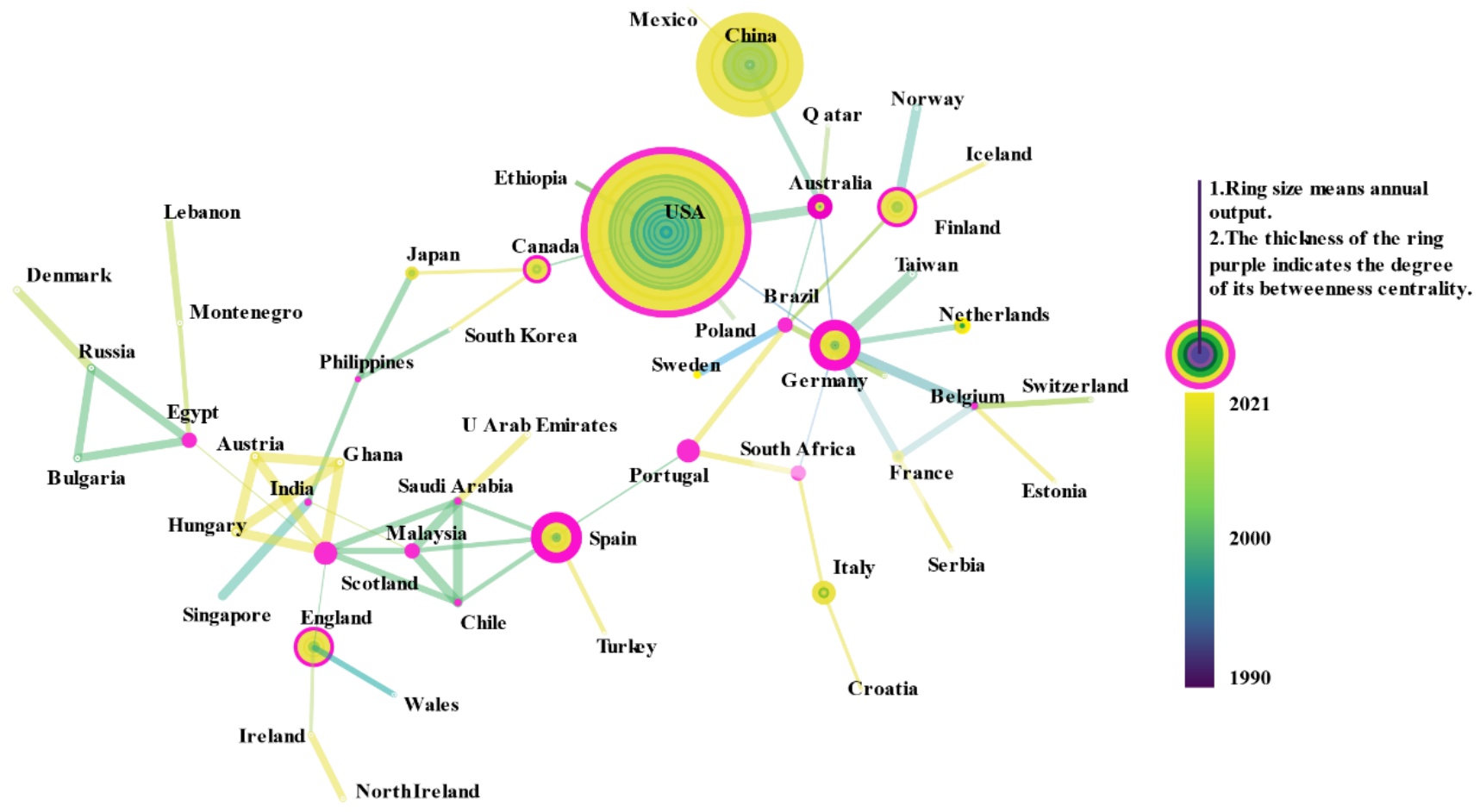

Figure 4. Mapping knowledge domains of coauthoring countries.

It can be seen intuitively from Figure 4 that Scotland $(B C=0.6)$, Spain $(B C=0.58)$, Germany $(B C=0.43)$, Australia $(B C=0.3)$, and the USA $(B C=0.27)$ have thick purple rings, which indicates that research articles published by these countries are of high value. This conclusion is also consistent with the data presented in Table 4.

\subsection{Disciplines and Topics Involved in CPCN in Buildings}

In 1990-2021, different research themes and topics related to CPCN in buildings were explored. Co-occurrence analysis not only detects research hotspots and trends for an item, it can also explain the affinities relationship between different items. We used the co-occurrence analysis module from CiteSpace to generate category and keyword co-occurrence knowledge maps for the data extracted from the WOS database.

\subsubsection{Subject Category Co-Occurrence Network}

Which disciplines are involved in CPCN in buildings? In the WOS database, each article belongs to at least one subject category [5]. A co-occurrence network of subject categories in CPCN in buildings was generated to show the research trends in and relationships between different subject categories. In terms of the attributes of the CiteSpace 
co-occurrence analysis module, we set the time slice as 3 years, conducted data visualization for the top 100 subjects in each time slice, and set a threshold of 100 in the knowledge graph to display the node label. Figure 5 shows a network with 88 nodes and 365 links, demonstrating that this research topic covers at least 88 subject categories and involves interdisciplinary research. The size of the node represents the number of articles contained in the category. The most common categories are 'Environmental Sciences \& Ecology', 'Energy \& Fuels', 'Engineering', and 'Environmental Sciences'. Although 'Materials Science', 'Urban Studies' and 'Architecture', etc., are much smaller than the other categories, they are also marked for reference. Table 5 lists the top 20 subject categories by the number of articles. The years in Table 5 represent when the first article on this research topic was published in each subject category. Research in the 'Materials Science', 'Physics', and 'Materials Science, and Multidisciplinary' fields began earlier than other disciplines, while papers on 'Environmental Sciences \& Ecology', 'Environmental Science', 'Science \& technology', and 'Green \& Sustainable Science \& Technology' were published relatively late, but these areas have developed rapidly.

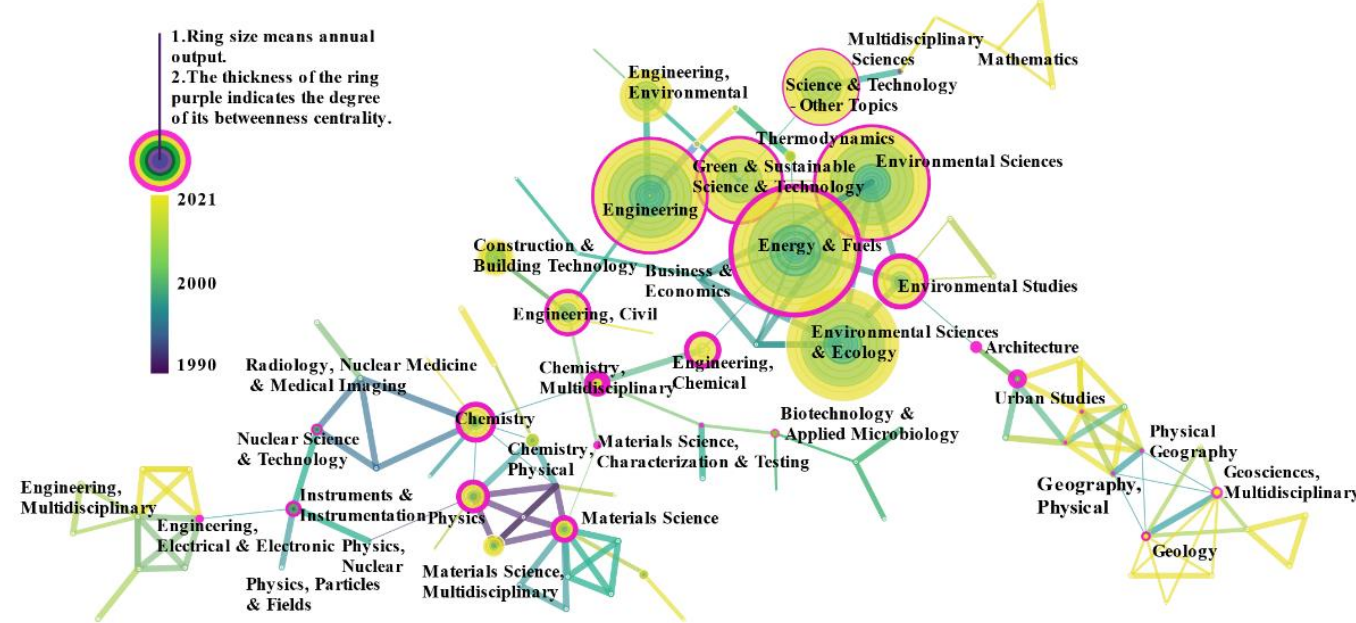

Figure 5. Subject categories involved in CPCN in buildings.

Table 5. Top 20 subject categories with the most publications on $\mathrm{CPCN}$ in buildings.

\begin{tabular}{ccccc}
\hline Rank & Subject Categories & Years & Count & Centrality \\
\hline 1 & Environmental Sciences \& Ecology & 2007 & 124 & 0.01 \\
2 & Energy \& Fuels & 1999 & 118 & 0.56 \\
3 & Engineering & 2001 & 118 & 0.23 \\
4 & Environmental Sciences & 2007 & 107 & 0.26 \\
5 & Science \& Technology-other Topics & 2006 & 97 & 0.16 \\
6 & Green \& Sustainable Science \& Technology & 2009 & 82 & 0.34 \\
7 & Environmental Studies & 2007 & 59 & 0.54 \\
8 & Engineering, Environmental & 2009 & 48 & 0.03 \\
9 & Construction \&Building Technology & 2011 & 42 & 0 \\
10 & Engineering, Civil & 2011 & 39 & 0.25 \\
11 & Chemistry & 2000 & 35 & 0.57 \\
12 & Materials Science & 1993 & 28 & 0.38 \\
13 & Physics & 1993 & 27 & 0.34 \\
14 & Engineering Chemical & 2006 & 24 & 0.52 \\
15 & Materials Science, Multidisciplinary & 1993 & 23 & 0 \\
16 & Nuclear science \& technology & 2000 & 20 & 0.13 \\
17 & Thermodynamics & 1999 & 18 & 0.03 \\
18 & Instruments \& Instrumentation & 2002 & 17 & 0.3 \\
19 & Chemistry, Physical & 2007 & 14 & 0.07 \\
20 & Physics, Nuclear & 1998 & 14 & 0.2 \\
\hline
\end{tabular}


In Figure 5, a purple circle means that the node has a high degree of BC, for example, Chemistry $(B C=0.57)$, Energy \& Fuels $(B C=0.56)$, Environmental Studies $(B C=0.54)$, Engineering Chemical $(\mathrm{BC}=0.52)$. This represents the turning points that connect different stages of research and have key impacts on the development of CPCN in buildings. The colors of link and node rings (form cold color to warm color) correspond to the years from 1990 to 2021. Figure 5 illustrates that the number of articles published in most disciplines has increased significantly since start of the 21st century.

CiteSpace divides the co-occurrence network of subject categories into clusters so that subject categories are closely linked in the same cluster but loosely connected between different clusters. As shown in Figure 6, the most common subject categories are mainly covered by Cluster \#1 and Cluster \#3, which indicates that using the log-likelihood ratio test method (LLR), the research content from 'Engineering', 'Green \& Sustainable Science \& Technology', 'Engineering Environmental', and 'Engineering Civil' can be extracted and summarized as 'Recycled Aggregate', and the research content from 'Environmental Studies', 'Environmental Sciences', 'Energy \& Fuels', and 'Environmental Sciences \& Ecology' can be extracted and summarized as 'Greenhouse Gas Emissions'.

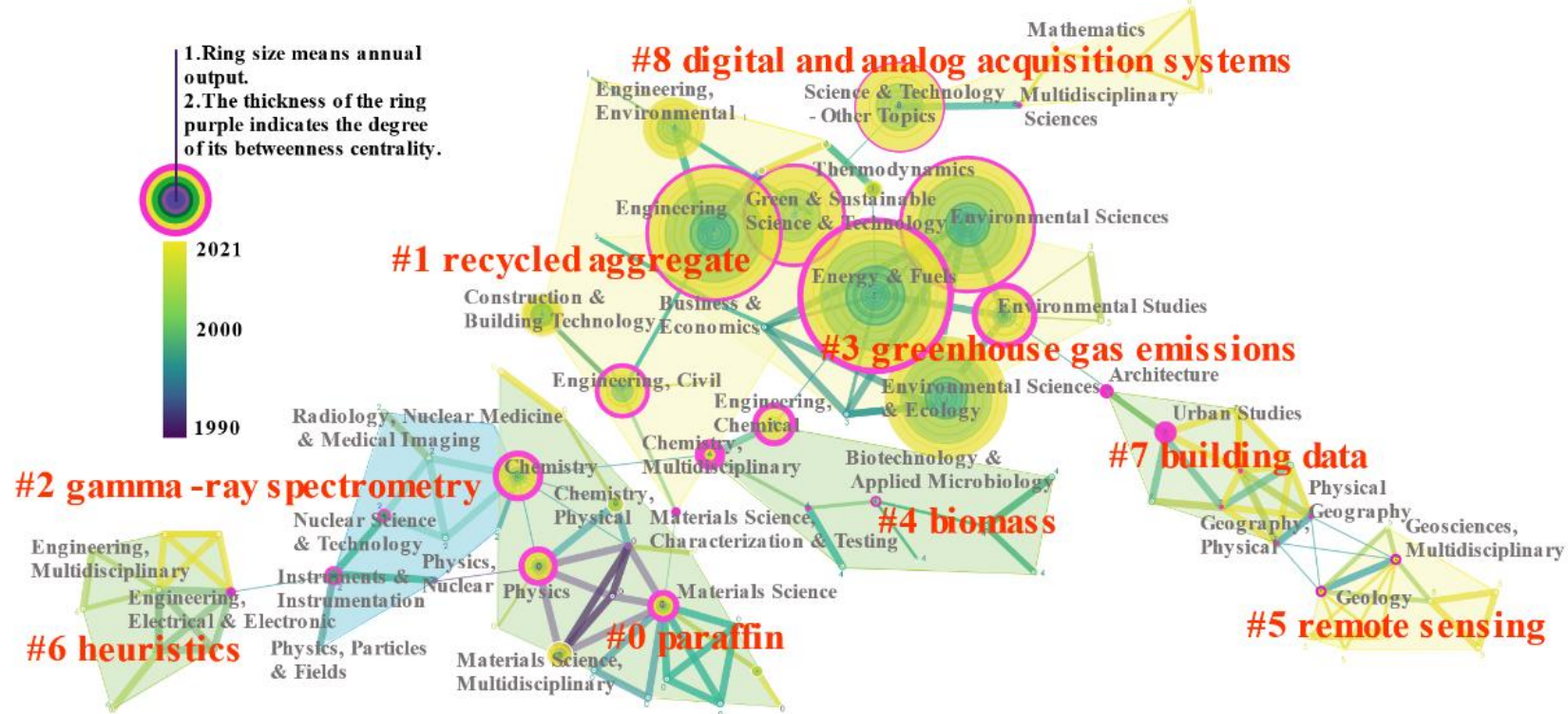

Figure 6. Cluster map of the co-occurrence of subject categories.

\subsubsection{Keyword Co-Occurrence Analysis}

Topics related to CPCN in the building sector can be described using keywords assigned to each article in the data set. The WOS database contains two types of keywords: the 'author keywords' provided by the author and the 'keywords plus' provided by the journals [5]. We used two sets of keywords from 364 records to make a timeline view using CiteSpace software. Figure 7 shows the research progress for each cluster, and this can be used to understand the changes in research topics. Each cluster is composed of several keywords, among which the clustering keywords are ranked on the right side of the Figure 7, and the time when the keywords first appear is presented at the top. The curved line in Figure 7 indicates the co-occurrence of different keywords. The thickness of the line shows the frequency of co-occurrence: the larger the cross node, the higher the intensity of the keyword bursts. It can be seen from Figure 7 that node 'System' (Cluster \#0), node 'Life Cycle Assessment' (Cluster \#1), node 'Energy consumption' (Cluster \#2), node ' $\mathrm{CO}_{2}$ emission' (Cluster \#2), node 'Energy consumption' (Cluster \#2), node 'Energy' (Cluster \#4), node 'Performance' (Cluster \#4), and node 'Impact' (Cluster \#6) have strong bursts. This shows that these topics have been widely studied by scholars, and this can be more accurately understood from Table 6. It is worth noting that a large number of keywords appeared in 2010 and continue to be studied so far. This shows 
that although the United Nations Climate Change Conference held in Copenhagen in December 2009 failed to produce the new international legal framework for man-made climate change [73], the Copenhagen Accord that resulted from the conference successfully promoted scientific research, and research in the field of buildings has been a positive response to the Copenhagen Accord.

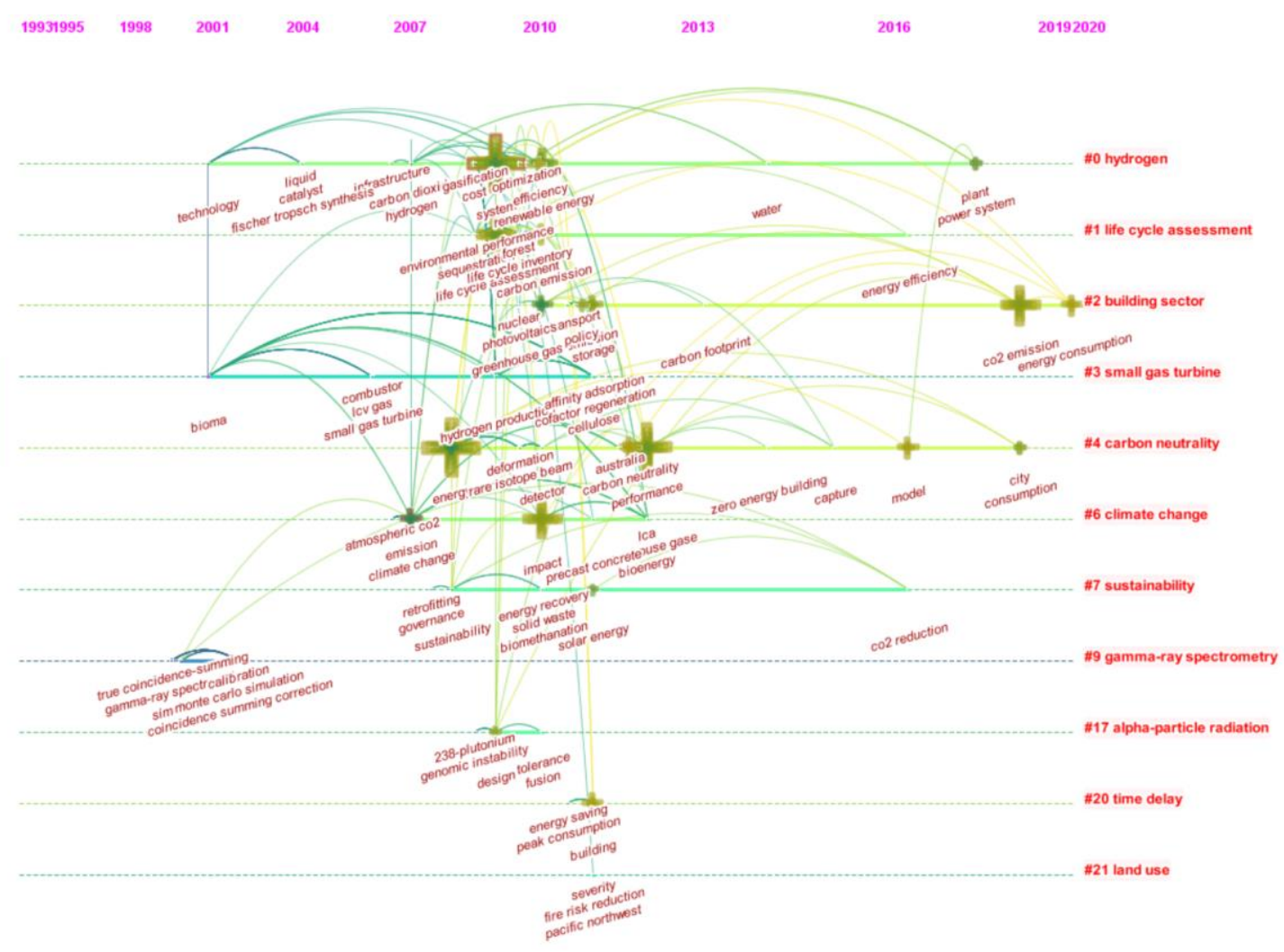

Figure 7. Keyword co-occurrence timeline view.

Table 6. Top 17 keywords with the strongest co-occurrence bursts for CPCN in buildings.

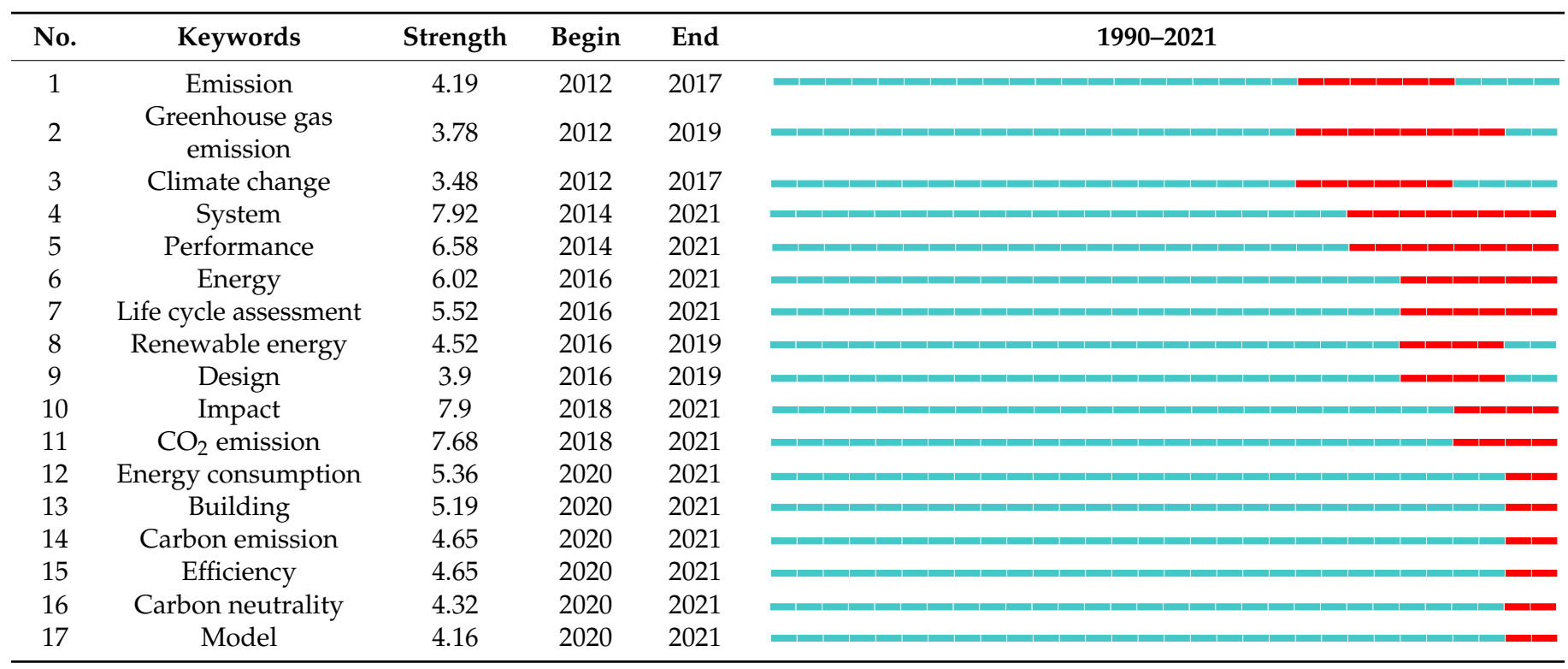

Table 6 lists the top 17 keywords with the strongest co-occurrence bursts (Red line segment represents the year of co-occurrence bursts), among which 'System', 'Impact', 
and ' $\mathrm{CO}_{2}$ emission' rank as the top three. 'Emission', 'Greenhouse gas emission', and 'Climate change' appeared relatively early. In 2020, the topics of 'Energy consumption', 'Building', 'Carbon emission', 'Efficiency', 'Carbon emission', and 'Model' have attracted wide attention from scholars. It is particularly noteworthy that although 'Impact' and ' $\mathrm{CO}_{2}$ emission' appeared in 2018, they have high co-occurrence bursts, which indicates that these topics have caught the eye of many scholars in the last three years.

\subsection{The Intellectual Structure of CPCN in Buildings}

In 1973, Small, an intelligence scientist from the United States, first proposed the concept of using co-citations to measure the relationship degree between documents [74]. At the same time that Small came up with this idea, Soviet intelligence scientist Marshakova had a similar idea.

When two articles/journals are frequently cited together, it is obvious that the two articles/journals are related in some respects. It has been proven that the network created in this method of co-citation can identify the research priorities of the scientific community, and the citation burst is a valuable means to track the development trend of research priorities [72].

\subsubsection{Journal Co-Citation Analysis}

The intensity and duration of the burst state are two important attributes of citation bursts. Table 7 lists the strongest citation burst journals for the entire dataset from 1990 to 2021 (Red line segment represents the year of co-citation bursts). 'P. Natl. Acad. Sci. Usa' and 'Energ. Environ. Sci.' are not only the earliest journals with citation bursts but also have lasted for the longest: 12 years. Although 'Sustainability' appeared late in the citation surge, the citation intensity was high, reaching 11.36 and producing the highest intensity of citation bursts, indicating that high-quality articles appeared in the journal. In the last two years, the journals 'Energies', 'Energy Proced.', 'Energ. Econ.' and 'Appl. Energ.' have had the strongest citation bursts, showing that relevant articles in these journals are worth referring to.

Table 7. Top 20 Cited Journals with the Strongest Citation Bursts.

\begin{tabular}{|c|c|c|c|c|c|}
\hline No. & Cited Journals & Strength & Begin & End & 1990-2021 \\
\hline 1 & P. Natl. Acad. Sci. Usa & 9.04 & 2008 & 2019 & \\
\hline 2 & Energ. Environ. Sci. & 8.30 & 2008 & 2019 & \\
\hline 3 & Int. J. Hydrogen Energ. & 6.65 & 2008 & 2016 & \\
\hline 4 & Biomass Bioenerg. & 5.32 & 2008 & 2013 & \\
\hline 5 & Bioresource Technol. & 4.63 & 2008 & 2013 & \\
\hline 6 & Environ. Sci. Technol. & 4.36 & 2008 & 2016 & \\
\hline 7 & J. Am. Chem. Soc. & 4.87 & 2011 & 2016 & \\
\hline 8 & Environ. Res. Lett. & 4.73 & 2011 & 2019 & \\
\hline 9 & Climate Change & 3.79 & 2011 & 2013 & \\
\hline 10 & Sol. Energy & 7.04 & 2014 & 2019 & \\
\hline 11 & Build. Res. Inf. & 4.93 & 2014 & 2016 & \\
\hline 12 & Phys. Chem. Chem. Phys. & 3.62 & 2014 & 2016 & \\
\hline 13 & Chem. Rev. & 3.62 & 2014 & 2016 & \\
\hline 14 & Energ. Buildings & 3.57 & 2014 & 2019 & \\
\hline 15 & Sustainability & 11.36 & 2017 & 2021 & \\
\hline 16 & Energies & 8.28 & 2017 & 2021 & \\
\hline 17 & Nat. Clim. Change & 6.12 & 2017 & 2019 & \\
\hline 18 & Energy Proced. & 4.98 & 2017 & 2021 & \\
\hline 19 & Energ. Econ. & 4.48 & 2017 & 2021 & \\
\hline 20 & Appl. Energ. & 4.37 & 2017 & 2021 & \\
\hline
\end{tabular}

\subsubsection{Document Co-Citation Analysis}

A research article usually quotes many references. The document co-citation analysis can not only determine the potential knowledge structure of a knowledge field, but it can 
also prove the number and authority of the cited documents. In order to determine the distribution of documents on CPCN in the building sector, we used CiteSpace to collect the top 10 documents with the most frequent co-citations in the references. Meanwhile, we obtained the number of citations from these 10 documents according to the WOS database, and this is presented in Table 8.

Table 8. The top 10 most co-cited articles.

\begin{tabular}{|c|c|c|c|c|c|}
\hline \multirow{2}{*}{ Rank } & Cited References & \multirow{2}{*}{ Year } & \multirow{2}{*}{ Co-Citation Times } & \multirow{2}{*}{ Times Cited } & \multirow{2}{*}{ Centrality } \\
\hline & Author, Year, Journal, Volume, Page, Doi & & & & \\
\hline 1 & $\begin{array}{c}\text { Zhou N., 2018, Nat. Energy, V3, P978, } \\
\text { doi:10.1038/s41560-018-0253-6 }\end{array}$ & 2018 & 6 & 85 & 0 \\
\hline 2 & $\begin{array}{c}\text { Ma M.D, 2017, J. Clean. Prod., V143, P784, } \\
\text { doi:10.1016/j.jclepro.2016.12.046 }\end{array}$ & 2017 & 5 & 93 & 0 \\
\hline 3 & $\begin{array}{c}\text { Tan X.C., 2018, Energ. Policy, V118, P429, } \\
\text { doi:10.1016/j.enpol.2018.03.072 }\end{array}$ & 2018 & 5 & 55 & 0 \\
\hline 4 & $\begin{array}{c}\text { Fargione J., 2008, Science, V319, P1235, } \\
\text { doi:10.1126/science.1152747 }\end{array}$ & 2008 & 4 & 2434 & 0 \\
\hline 5 & $\begin{array}{l}\text { Sartori I., 2012, Energ. Buildings, V48, P220, } \\
\text { doi:10.1016/j.enbuild.2012.01.032 }\end{array}$ & 2012 & 4 & 442 & 0 \\
\hline 6 & $\begin{array}{c}\text { Dong K.Y., 2018, Renew. Sust. Energ. Rev., } \\
\text { V94, P419, } \\
\text { doi:10.1016/j.rser.2018.06.026 }\end{array}$ & 2018 & 4 & 94 & 0 \\
\hline 7 & $\begin{array}{l}\text { Ma M.D., 2018, Sci. Total Environ., V634, } \\
\text { P884, } \\
\text { doi:10.1016/j.scitotenv.2018.04.043 }\end{array}$ & 2018 & 4 & 75 & 0 \\
\hline 8 & $\begin{array}{l}\text { Lin B.Q., 2015, Build. Environ., V92, P418, } \\
\text { doi: 10.1016/j.buildenv.2015.05.020 }\end{array}$ & 2015 & 4 & 61 & 0 \\
\hline 9 & $\begin{array}{l}\text { McNeil M.A., 2016, Energ. Policy, V97, P532, } \\
\text { doi:10.1016/j.enpol.2016.07.033 }\end{array}$ & 2016 & 4 & 49 & 0 \\
\hline 10 & $\begin{array}{c}\text { Wu C.B., 2018, J. Clean. Prod., V172, P466, } \\
\text { doi:10.1016/j.jclepro.2017.10.216 }\end{array}$ & 2018 & 4 & 46 & 0 \\
\hline
\end{tabular}

It can be seen from Table 8 that 8 of the top 10 highly cited papers have been published since 2015, indicating that research on CPCN in buildings has developed rapidly in the past five years. Specifically, research articles by Zhou N. (2018), Ma M.D. (2017), and Tan X.C. (2009) received six, five, and five co-citations, respectively, placing these articles in the top three. Zhou N. et al. (2018) explored the ECCE of China's building sector in 2050 through four scenarios with different application degrees of new energy efficiency or renewable energy policies and predicted the peak times of different scenarios. Moreover, it is pointed out that the focus of energy savings and carbon emission abatement in the building sector should be on a system that can achieve energy efficiency rather than on technology, and the impact of individual policies should be assessed in future studies. Further, the behavior of human and occupants should be given extra consideration [75]. We searched 85 papers citing this article through WOS (Table A1 in the Appendix A) and found 3 papers with high numbers of citations: Ma M.D. (2019) with 104 citations, Liang Y. (2019) with 73 citations, and Ma M.D. (2020) with 70 citations. In terms of the three highly cited papers, Ma M.D. et al. (2019) analyzed the factors mitigating the carbon dioxide $\left(\mathrm{CO}_{2}\right)$ intensity in China based on a household scale through decomposition and found that the housing price-income ratio, housing purchasing power, and population size per household are three housing economic indicators linked to a significantly reduced $\mathrm{CO}_{2}$ intensity [76]. Liang Y. et al. (2019) used decomposition and decoupling methods to determine the decoupling effect of residential buildings in China and explored the decoupling modes of four megacities by mapping the carbon Kuznets curves of residential 
buildings [77]. The third article, also from Ma M.D. (2020), through the construction of China's energy and emission peak historical carbon emission reduction assessment and simulation, showed that residential construction will produce peak carbon emissions in 2037, and through a sensitivity analysis, concluded that, per capita, building area and urban residential building energy consumption have the most significant impacts on the emissions peak of uncertainty [7].

Considering that it is difficult to quantify the factors affecting the national building energy savings (NBES), Ma M.D. et al. (2017), the author of the second article presented in Table 8, proposed a method that combines the IPAT model and LMDI decomposition (Logarithmic Mean Divisia Index, LMDI) to calculate the national building energy savings. By comparing the China's calculated NBES with the official plan, it was found that China has exceeded its building energy-efficiency target [44]. On this basis, Ma M.D. et al. (2017) (i.e., the seventh article in Table 8) decomposed five driving forces of Chinese commercial building carbon emissions (CCBCE) to assess carbon abatement in Chinese commercial building value in 2001-2015, further breaking down the research from NBES to CCBCE [78].

In the third article from 'Energ. Policy' presented in Table 8, Tan X.C. et al. (2018) developed a bottom-up model to predict the future carbon emissions trend for China's building sector. This shows that, under the policy scenario, the low-carbon policy of the construction industry can only slow down but not completely curb carbon dioxide emissions. Research shows that coordinated emission reduction between sectors has a better effect than coordinated emission reduction by one sector [79].

From the 4 th to the 10th articles in Table 8, although there were four co-citations in total, the total citation times differed greatly. The 4th article by Fargione J. (2008) from 'SCIENCE' was cited 2434 times, while that by Sartori I. (2012) from 'Energ. Buildings' was cited 50 times. Fargione J. et al. (2008) proposed that although biofuels are a potential low-carbon energy source, different production methods determine whether biofuels can save carbon [80]. Sartori I. et al. (2012) proposed a consistent definition framework that includes five standards and corresponding sub-standards to describe the characteristics of net zero energy buildings [81]. Lin B.Q. et al. (2015) conducted empirical research on the determinants of carbon dioxide emissions in relation to building energy and evaluated the carbon dioxide emission reduction potential of buildings [82]. The 9th article is also from the 'Energ. Policy'. McNeil M.A. et al. (2016) quantified the potential impact of energy efficiency projects in China's building sector on energy saving and emission reduction by using a bottom-up modeling framework [83].

\subsubsection{Author Co-Citation Analysis}

If an author has a high number of co-citations, we consider their research to be of high value. In order to further understand the scholars in this field who have attracted attention, we analyzed their strongest citation bursts, as shown in Table 9 (Red line segment represents the year of co-citation bursts). Professor Metz B. and Professor Lewis N.S. had the longest citation burst duration of five years, followed by Sartori I. It is noteworthy that Zhang Y. had the highest burst intensity, although the burst state only lasted for two years. The citation outbreak years of the four authors were all after 2010, which indicates that the articles of these four authors have played important reference value in the past decade and have aroused the interest of other scholars.

Table 9. Top 4 Cited Authors with the Strongest Citation Bursts.

\begin{tabular}{cccccc}
\hline No. & Cited Authors & Strength & Begin & End & 1990-2021 \\
\hline 1 & Metz B. & 3.8 & 2011 & 2016 & \\
2 & Lewis N.S. & 3.68 & 2011 & 2016 & \\
3 & Sartori I. & 3.61 & 2014 & 2019 & \\
4 & Zhang Y. & 4.47 & 2017 & 2019 & \\
\hline
\end{tabular}


We also selected the top 10 co-cited authors, with co-citations ranging from eight to six (Table 10). The top four cited authors with the strongest citation bursts all appear in Table 10, ranking 9th, 8 th, 5th and 1st according to the number of co-citations. For the articles retrieved from the subject search, there were five articles by five authors. Notably, Chen X. (1st author) and Zhang Y. (2020) topped the list. By working together at the sectoral level, the two scholars predicted emission peaks for four carbon pillar industries: industry, construction, transport, and agriculture. Compared with the Chinese government's commitment for $\mathrm{CO}_{2}$ emissions to peak around 2030 [84], they found that the peak time was six years later, and it was concluded that the delay was mainly due to the industrial, building, and transportation sectors. This research provides a reference for us to further determine the time of peak carbon emissions in the building sector [85].

Table 10. Top 10 most co-cited Authors.

\begin{tabular}{|c|c|c|c|c|c|}
\hline Rank & Author & Year & Co-Citations & Title & Times Cited \\
\hline 1 & Zhang Y. & 2017 & 8 & $\begin{array}{c}\text { Analysis on the carbon emission peaks of } \\
\text { China's industrial, building, transport, and } \\
\text { agricultural sectors }\end{array}$ & 44 \\
\hline 2 & Chen X. & 2020 & 8 & $\begin{array}{c}\text { Analysis on the carbon emission peaks of } \\
\text { China's industrial, building, transport, and } \\
\text { agricultural sectors }\end{array}$ & 44 \\
\hline 3 & Zhou N. & 2020 & 8 & $\begin{array}{c}\text { Exploring potential pathways towards urban } \\
\text { greenhouse gas peaks: A case study of } \\
\text { Guangzhou, China }\end{array}$ & 9 \\
\hline 4 & Lin B.Q. & 2020 & 8 & / & 0 \\
\hline 5 & Sartori I. & 2014 & 7 & / & 0 \\
\hline 6 & Wang J. & 2020 & 7 & $\begin{array}{l}\text { Energy demand and carbon emission peak } \\
\text { forecasting of Beijing based on leap energy } \\
\text { simulation method }\end{array}$ & 0 \\
\hline \multirow[b]{2}{*}{7} & \multirow[b]{2}{*}{ Wang Y. } & \multirow[b]{2}{*}{2020} & \multirow[b]{2}{*}{7} & $\begin{array}{c}\text { Feasibility assessment of the carbon emissions } \\
\text { peak in China's construction industry: Factor } \\
\text { decomposition and peak forecast }\end{array}$ & 14 \\
\hline & & & & $\begin{array}{c}\text { Feasibility of peaking carbon emissions of the } \\
\text { power sector in China's eight regions: } \\
\text { decomposition, decoupling, and } \\
\text { prediction analysis }\end{array}$ & 7 \\
\hline 8 & Lewis N.S. & 2011 & 6 & / & 0 \\
\hline 9 & Metz B. & 2011 & 6 & / & 0 \\
\hline 10 & Zhang Y.J. & 2020 & 6 & / & 0 \\
\hline
\end{tabular}

Compared to the research on the potential of energy efficiency and carbon dioxide emissions in the Chinese building sector conducted by Zhou N. et al. (2018), which was mentioned in the previous section, Zhou N. et al. (2019) took Guangzhou as an example to study the potential pathway of the urban greenhouse gas peak from the city level. The research revealed that, in the long run, the energy-saving strategy of the construction industry will be very important to Guangzhou [86]. Similarly, Wang J. et al. (2020) predicted the energy demand and peak carbon emissions for Beijing and found that enhancing the energy efficiency of the tertiary industry and improving the industrial structure is an effective way to decrease energy use and carbon emissions [87].

Two articles by Wang Y. analyzed the factors leading to peak carbon emissions production by China's building industry and the feasibility of reaching peak carbon emissions in the eight major regions of China's power industry. The results show that GDP has the highest cumulative contribution to carbon emissions in the building sector in China [88] 
and is also the main factor affecting the carbon emissions of the power industry in eight regions [89].

\section{Discussion}

This study reviewed literature on CPCN in buildings from 1990 to 2021 and summarized current research hotspots. It should be pointed out that the above research content was determined through an objective analysis and does not cover all topics that need to be researched.

At present, research on CPCN in the building sector is mainly focused on developed countries and major economies [90-94], and further cooperation between authors, institutions, and countries is needed to keep the global temperature rise to below $1.5^{\circ} \mathrm{C}$ above pre-industrial levels [95]. Take China, for example, the reduction of the ECCE potential of China's building sector has been estimated under various scenarios [7,75,79,96,97]. India is one of the top three emitters worldwide, and its energy demand increases obviously with the rapid growth of economy and population [98]. In the upcoming two decades, India's $\mathrm{CO}_{2}$ emissions are expected to increase by $50 \%$, and buildings are one of the main drivers. The building sector in India accounted for $24 \%$ of the nationwide $\mathrm{CO}_{2}$ emissions in 2019, and the indirect emissions released by the building sector nearly tripled from 2000 to 2017. India's urbanization level aims to reach $40 \%$ in the next one decade, which will promote the increase of ECCE in the building sector significantly at the same time [99]. As the ECCE of non-developed countries in the world will experience the levels of their predecessors with economic and population growth, research on CPCN in the building sector of developing countries cannot be ignored [96,100]. So, by expanding the data set, especially the future ECCE research in developing countries [101], the research scope can be extended from the country to the world, and the civil building peak carbon emission under different emission standards in different countries can be researched from a global perspective.

At the provincial and municipal building sector level, potential paths for urban CPCN have also been extensively explored [102-105], and further detailed research on CPCN has been carried out for commercial and residential buildings [52,106-108]. For example, Wu et al. conducted a modeling analysis on Qingdao's future $\mathrm{CO}_{2}$ emissions (including the number of emission peaks and the time of occurrence) using the STIRPAT model [109]. Huang et al. calculated the carbon footprint of Xiamen city and conducted a low-carbon scenario analysis [110]. Li et al. took Jiangsu Province as an example to analyze how to achieve the carbon emission peak for the provincial building sector [111]. Goomi et al. [112], Farzaneh et al. [113], and Jing et al. [114] developed low-carbon development models for different cities to evaluate low-carbon development scenarios in the city system. With the growth of economy and population, the construction area of the county seat has grown steadily [115]. Based on the data from the China Statistical Yearbook, we illustrated the changes of construction area and population size in county seat in China (see Figure 8) [116]. It shows the growth of population and construction area have the same trend, which means the decrease of ECCE in the county seat faces the huge challenge. Most of the existing studies on CPCN in the building sector focused on the city level, and study with case area focused on the county level has been barely discussed [117]. The potential of energy saving and emission abatement in county seat is worth researching.

The thermal integrity of residential buildings in rural areas is poor $[118,119]$, and the comfort level is not as good as that of cities $[120,121]$. In China, the energy use of rural residential buildings accounts for nearly $14 \%$ of the total building energy consumption [122]. According to the China Statistical Yearbook, in 2020, stock of China's rural residential buildings reached 26.6 billion $\mathrm{m}^{2}$, which is the equivalent of constructing an entire New York City every month for over three decades [116]. Besides, the floor area per capita in rural residential buildings increased from $24.8 \mathrm{~m}^{2}$ in 2000 to $47.3 \mathrm{~m}^{2}$ in 2018 [123]. With the implementation of the rural revitalization plan issued by the Chinese government [124], the ECCE of rural residential buildings will keep the increase to meet the demand of rural household and also to obtain a goal of thermal comfort in the future [125-129]. Since 
research on the CPCN of rural residential buildings is scarce at present, it will become necessary in the future.

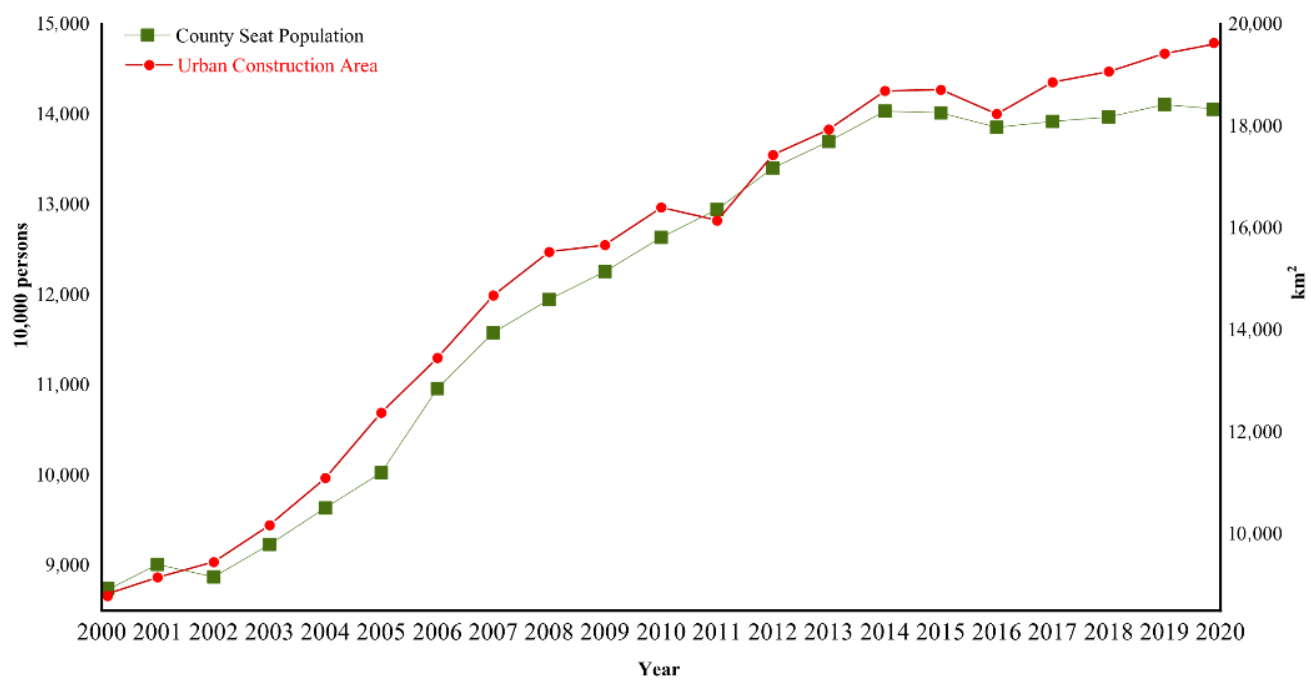

Figure 8. Changes of population size and construction area of county seat in China (2000-2020).

Based on the existing review and analysis, in order to further refine the work on CPCN in the building sector, this review paper proposes the above three future research directions.

\section{Conclusions}

This paper conducted a bibliometric analysis on literature published on CPCN in the building sector. Knowledge maps were obtained through information visualization techniques. This paper presents the research hotspots and development trends on CPCN in buildings and provides references for researchers to explore further.

By analyzing the contributions of and cooperation among authors, institutions, and countries as well as the trend of published articles, we can conclude that although the number of articles is relatively small at present, it has grown rapidly since 2005, especially in developed countries and China. The United States and China cooperate the most with other countries, and other countries cooperate less with each other. Collaboration among most institutions and authors is relatively rare and non-extensive.

The co-occurrence analysis on disciplines and themes revealed that the most common disciplines are 'Environmental Sciences \& Ecology', 'Energy \& Fuels', 'Engineering', 'Environmental Sciences and Materials Science, Physics', and' Materials Science'. Multidisciplinary research in this field started earlier than other disciplines, while the environmental science and science technology areas were introduced to this field relatively late but have developed rapidly. The 'Chemistry', 'Energy \& Fuels', 'Environmental Studies', and 'Engineering Chemical' areas have high centrality, indicating that they are turning points connecting different years of research and have greatly influenced the development of CPCN in buildings. Through a cluster analysis of disciplines, the 'Green \& Sustainable', 'Science \& Technology', 'Engineering', 'Engineering Civil', and 'Engineering Environmental' research content can be extracted and summarized as Recycled Aggregate, and the 'Energy \& Fuels', 'Environmental Studies', 'Environmental Sciences', and 'Environmental Sciences \& Ecology' research content can be extracted and summarized as Greenhouse Gas Emissions.

As indicated by the analysis of keyword co-occurrence, a large number of keywords appeared in 2010 and continue to be studied. 'System', 'Life Cycle Assessment', 'Energy consumption', 'CO $\mathrm{CO}_{2}$ emission', 'Energy consumption', 'Energy consumption', 'Energy consumption', 'Performance', and 'Impact' have strong co-occurrence bursts. This shows that these topics have been widely studied by scholars, and although 'Impact' and ' $\mathrm{CO}_{2}$ 
emission' appeared in 2018, they showed high co-occurrence bursts, which indicates that these topics have attracted significant attention among scholars in the past three years.

In terms of aspects of the intellectual structure of CPCN in buildings, the analysis of journal co-citations showed that 'P. Natl. Acad Sci. Usa' and 'Energ. Environ. Sci.' are not only the earliest journals with citation bursts but also have lasted the longest: 12 years. Although the citation surge for 'Sustainability' appeared late, the citation intensity was high. This journal had the highest intensity of citation bursts, indicating that high-quality articles appeared in the journal. In the last two years, the journals 'Energies', 'Energy Proced.', 'Energ. Econ.', and 'Appl. Energ.' had the strongest citation bursts, which shows that the relevant articles in these journals are worth referring to. Through further analysis of article co-citations, we found that these authors and their articles have aroused the interest of other scholars: Zhou N. (2018), Ma M.D. (2017), and Tan X.C. (2009) received six, five, and five co-citations, respectively, ranking them within the top three. These were followed by Fargione J (2008), Sartori I (2012), Lin B.Q. (2015), and McNeil M.A. (2016). In addition, the analysis of the authors' strongest citation bursts found that the citation bursts of Professors Metz B. and Lewis N.S. lasted the longest, followed by that of Professor Sartori. The citation outbreak years of the four authors are all after 2010, which indicates that the articles by these four authors have had important reference value in the past decade and have aroused the interest of other scholars.

This article provides practitioners and researchers with a comprehensive overview of the current situation, future agenda, and research gaps of CPCN in the building sector. Researchers should fill in the knowledge gaps according to the recommended directions, thereby expanding the research body of CPCN in the building sector.

Author Contributions: Conceptualization, M.M., Z.M. and W.C.; methodology, M.M.; software, Z.S.; validation, Z.S., X.X. and S.Z.; formal analysis, Z.S., M.C. and L.C.; investigation, Z.S.; resources, M.M.; data curation, Z.S.; writing—original draft preparation, Z.S.; writing—review and editing, M.M.; visualization, Z.S. and M.M.; supervision, Z.M.; project administration, Z.M.; funding acquisition, Z.M. and M.M. All authors have read and agreed to the published version of the manuscript.

Funding: This study was supported by the National Planning Office of Philosophy and Social Science Foundation of China (21CJY030 and 18BJL034), the Beijing Natural Science Foundation (8224085), the China Postdoctoral Science Foundation (2020M680020), the Shuimu Tsinghua Scholar Program of Tsinghua University (2019SM139), and the Fundamental Research Funds for the Central Universities of China (2020CDJSK03YJ07).

Institutional Review Board Statement: Not applicable.

Informed Consent Statement: Not applicable.

Data Availability Statement: Raw data available at https:/ /www.webofscience.com/wos/alldb / basic-search (accessed on 13 December 2021).

Conflicts of Interest: The authors declare no conflict of interest. The funders had no role in the design of the study; in the collection, analyses, or interpretation of data; in the writing of the manuscript, or in the decision to publish the results.

$\begin{array}{ll}\text { Abbreviations } \\ \text { BC } & \text { betweenness centrality } \\ \text { CPCN } & \text { Carbon peak and carbon neutrality } \\ \text { CCBCE } & \text { Chinese commercial building carbon emissions } \\ \text { ECCE } & \text { Energy consumption and carbon emissions } \\ \text { IPAT } & \text { I = Human Impact, P = Population, A = Affluence, T = Technology } \\ \text { LMDI } & \text { Logarithmic Mean Divisia Index } \\ \text { NBES } & \text { National building energy savings } \\ \text { TLS } & \text { Total link strength }\end{array}$




\section{Appendix A}

Table A1. Citing articles of 'Zhou N., 2018, NAT. ENERGY, V3, P978, doi:10.1038/s41560-018-0253-6'.

\begin{tabular}{|c|c|c|c|c|}
\hline \multirow{2}{*}{ Rank } & \multirow{2}{*}{$\begin{array}{c}\text { Citing Articles } \\
\text { Author, Year, Journal, Volume, Page/Article Number, doi }\end{array}$} & \multirow{2}{*}{ Type } & \multirow{2}{*}{ Times Cited } & \multirow{2}{*}{ Reference } \\
\hline & & & & \\
\hline 1 & $\begin{array}{c}\text { Ma M.D., 2019, Energ. Convers. Manage., V198, } \\
\text { Article No.111915, } \\
\text { doi:10.1016/j.enconman.2019.111915 }\end{array}$ & Article & 104 & [76] \\
\hline 2 & $\begin{array}{l}\text { Liang Y., 2019, Sci. Total Environ., V677, P315-327, } \\
\text { doi:10.1016/j.scitotenv.2019.04.289 }\end{array}$ & Article & 73 & [77] \\
\hline 3 & $\begin{array}{l}\text { Ma M.D., 2020, Appl. Energ., V273, Article No.115247, } \\
\text { doi:10.1016/j.apenergy.2020.115247 }\end{array}$ & Article & 70 甲 & [7] \\
\hline 4 & $\begin{array}{l}\text { Liu W., 2019, J. Energy Chem., V1, Article No. 100008, } \\
\text { doi:10.1016/j.enchem.2019.100008 }\end{array}$ & Review & 40 & [130] \\
\hline 5 & $\begin{array}{l}\text { Langevin J., 2019, Joule, V3, P2403-2424, } \\
\text { doi:10.1016/j.joule.2019.07.013 }\end{array}$ & Article & 27 & [131] \\
\hline 6 & $\begin{array}{l}\text { Zhang X.G., 2019, J. Co } \text { Co }_{2} \text { Util., V33, P394-404, } \\
\text { doi:10.1016/j.jcou.2019.06.019 }\end{array}$ & Article & 27 & [132] \\
\hline 7 & $\begin{array}{c}\text { Jiang J.J., 2019, Renew. Sust. Energ. Rev., V112, P813-833, } \\
\text { doi:10.1016/j.rser.2019.06.024 }\end{array}$ & Review & 23 & [133] \\
\hline 8 & $\begin{array}{l}\text { Zhang X., 2020, Appl. Energ., V261, Article No. 114353, } \\
\text { doi:10.1016/j.apenergy.2019.114353 }\end{array}$ & Article & 22 & [134] \\
\hline 9 & $\begin{array}{c}\text { Khanna N., 2020, Appl. Energ., V242, P12-26, } \\
\text { doi:10.1016/j.apenergy.2019.03.116 }\end{array}$ & Article & 21 & [135] \\
\hline 10 & $\begin{array}{l}\text { Li B., 2019, Sci. Total Environ., V706, Article No.135716, } \\
\text { doi:10.1016/j.scitotenv.2019.135716 }\end{array}$ & Article & 20 & [88] \\
\hline 11 & $\begin{array}{l}\text { Cao Z., 2019, Appl. Energ., V238, P 442-452, } \\
\text { doi:10.1016/j.apenergy.2019.01.106 }\end{array}$ & Article & 19 & [136] \\
\hline 12 & $\begin{array}{l}\text { Pan Y., 2020, Appl. Energ., V268, Article No.114965, } \\
\text { doi:10.1016/j.apenergy.2020.114965 }\end{array}$ & Article & 16 & [137] \\
\hline 13 & $\begin{array}{c}\text { Dai B.M., 2020, Energ. Convers. Manage., V209, } \\
\text { Article No.112594, } \\
\text { doi:10.1016/j.enconman.2020.112594 }\end{array}$ & Article & 15 & [138] \\
\hline 14 & $\begin{array}{l}\text { Guo S.Y., 2021, Energy, V214, Article No.119063, } \\
\text { doi:10.1016/j.energy.2020.119063 }\end{array}$ & Article & 13 & [92] \\
\hline 15 & $\begin{array}{l}\text { Duan H.M., 2020, J. Clean. Prod., V260, Article No.120929, } \\
\text { doi:10.1016/j.jclepro.2020.120929 }\end{array}$ & Article & 12 & [139] \\
\hline 16 & $\begin{array}{l}\text { Xian Y.J., 2019, J. Clean. Prod., V221, P457-468, } \\
\text { doi:10.1016/j.jclepro.2019.02.266 }\end{array}$ & Article & 10 & [140] \\
\hline 17 & $\begin{array}{l}\text { Wang Y.S., 2020, J. Clean. Prod., V251, Article No. 119637, } \\
\text { doi:10.1016/j.jclepro.2019.119637 }\end{array}$ & Article & 9 & [141] \\
\hline 18 & $\begin{array}{l}\text { Li W., 2019, J. Mater. Chem. A, V7, P25010-25019, } \\
\text { doi:10.1039/c9ta09227g }\end{array}$ & Article & 9 & [142] \\
\hline 19 & $\begin{array}{l}\text { Chen Y.X., 2020, Energ. Buildings, V222, Article No.110100, } \\
\text { doi:10.1016/j.enbuild.2020.110100 }\end{array}$ & Article & 8 & [143] \\
\hline 20 & $\begin{array}{c}\text { Zhang S.C., 2021, Energ. Buildings, V241, } \\
\text { Article No.110938, } \\
\text { doi:10.1016/j.enbuild.2021.110938 }\end{array}$ & Article & 7 & [144] \\
\hline
\end{tabular}


Table A1. Count.

\begin{tabular}{|c|c|c|c|c|}
\hline \multirow{2}{*}{ Rank } & Citing Articles & \multirow{2}{*}{ Type } & \multirow{2}{*}{ Times Cited } & \multirow{2}{*}{ Reference } \\
\hline & Author, Year, Journal, Volume, Page/Article Number, doi & & & \\
\hline 21 & $\begin{array}{c}\text { Mata E., 2020, Environ. Res. Lett., V15, Article No.113003, } \\
\text { doi:10.1088/1748-9326/abb69f }\end{array}$ & Review & 7 & [145] \\
\hline 22 & $\begin{array}{l}\text { Zhu W.N., 2020, J. Clean. Prod., V269, Article No. 122438, } \\
\text { doi:10.1016/j.jclepro.2020.122438 }\end{array}$ & Article & 7 & [146] \\
\hline 23 & $\begin{array}{l}\text { Liu W., 2019, Energ. Convers. Manage., V199, } \\
\text { Article No. 111943, } \\
\text { doi:10.1016/j.enconman.2019.111915 }\end{array}$ & Article & 7 & [147] \\
\hline 24 & $\begin{array}{c}\text { Deb C., 2021, Renew. Sust. Energ. Rev., V144, } \\
\text { Article No.110990, } \\
\text { doi:10.1016/j.rser.2021.110990 }\end{array}$ & Review & 6 & [148] \\
\hline 25 & $\begin{array}{l}\text { Zhang S.C., 2020, Energy, V213, Article No. 118792, } \\
\text { doi:10.1016/j.energy.2020.118792 }\end{array}$ & Article & 6 & [149] \\
\hline 26 & $\begin{array}{l}\text { Memon S., 2020, Energ. Buildings, V227, } \\
\text { Article No. 110430, } \\
\text { doi:10.1016/j.enbuild.2020.110430 }\end{array}$ & Article & 6 & [150] \\
\hline 27 & $\begin{array}{l}\text { Liu Q.B., 2020, Energ. Buildings, V224, Article No. 110242, } \\
\text { doi:10.1016/j.enbuild.2020.110242 }\end{array}$ & Article & 6 & [151] \\
\hline 28 & $\begin{array}{l}\text { Yu B.Y., 2020, Ecol. Econ., V13, Article No.3210, } \\
\text { doi:10.1016/j.ecolecon.2020.106706 }\end{array}$ & Article & 6 & [152] \\
\hline 29 & $\begin{array}{c}\text { Ding C., 2021, Energies, V14, Article No. 7461, } \\
\text { doi:10.3390/en13123210 }\end{array}$ & Article & 6 & [153] \\
\hline 30 & $\begin{array}{l}\text { Li H.M., 2021, Energ. Buildings, V244, Article No. 111011, } \\
\text { doi:10.1016/j.enbuild.2021.111011 }\end{array}$ & Article & 5 & [154] \\
\hline 31 & $\begin{array}{l}\text { Li H.R., 2021, Energ. Convers. Manage., V231, } \\
\text { Article No. 113648, } \\
\text { doi:10.1016/j.enconman.2020.113648 }\end{array}$ & Article & 5 & [155] \\
\hline 32 & $\begin{array}{l}\text { Liu P., 2020, Appl. Energ., V277, Article No. 115546, } \\
\text { doi:10.1016/j.apenergy.2020.115546 }\end{array}$ & Article & 5 & [156] \\
\hline 33 & $\begin{array}{r}\text { Zhang L.H., 2020, J. Clean. Prod., V271, Article No.122696, } \\
\text { doi:10.1016/j.jclepro.2020.122696 }\end{array}$ & Article & 5 & [157] \\
\hline 34 & $\begin{array}{c}\text { Mathew D., 2020, IET Power Electron., V13, P1487-1499, } \\
\text { doi:10.1049/iet-pel.2019.1237 }\end{array}$ & Review & 5 & [158] \\
\hline 35 & $\begin{array}{l}\text { Li L.X., 2021, Energy, V227, Article No. 120460, } \\
\text { doi:10.1016/j.energy.2021.120460 }\end{array}$ & Article & 4 & [159] \\
\hline 36 & $\begin{array}{c}\text { Mahapatra B., 2021, Energy, V227, Article No. 120485, } \\
\text { doi:10.1016/j.energy.2021.120485 }\end{array}$ & Article & 4 & [160] \\
\hline 37 & $\begin{array}{l}\text { Nematchoua M.K., 2020, Renew. Energ., V162, P81-97, } \\
\text { doi:10.1016/j.renene.2020.07.141 }\end{array}$ & Article & 4 & [161] \\
\hline 38 & $\begin{array}{c}\text { Levesque A., 2021, Environ. Res. Lett., V16, } \\
\text { Article No. 054071, } \\
\text { doi:10.1088/1748-9326/abdf07 }\end{array}$ & Article & 3 & [162] \\
\hline 39 & $\begin{array}{l}\text { Yan B., 2021, Renew. Energ., V54, P 2193-2220, } \\
\text { doi:10.1007/s10462-020-09902-w }\end{array}$ & Review & 3 & [163] \\
\hline 40 & $\begin{array}{c}\text { Shi Q.W., 2020, Sustainability, V12, Article No. 2695, } \\
\text { doi:10.3390/su12072695 }\end{array}$ & Article & 3 & [164] \\
\hline 41 & $\begin{array}{c}\text { Wu W.T., 2020, Renew. Sust. Energ. Rev., V117, } \\
\text { Article No. 109516, } \\
\text { doi:10.1016/j.rser.2019.109516 }\end{array}$ & Article & 3 & [165] \\
\hline
\end{tabular}


Table A1. Count.

\begin{tabular}{|c|c|c|c|c|}
\hline \multirow{2}{*}{ Rank } & Citing Articles & \multirow{2}{*}{ Type } & \multirow{2}{*}{ Times Cited } & \multirow{2}{*}{ Reference } \\
\hline & Author, Year, Journal, Volume, Page/Article Number, doi & & & \\
\hline 42 & $\begin{array}{c}\text { Yu L., 2021, Ieee Internet Things, V8, P 12046-12063, } \\
\text { doi:10.1109/JIOT.2021.3078462 }\end{array}$ & Review & 2 & [166] \\
\hline 43 & $\begin{array}{l}\text { Zhong X.Y., 2021, J. Clean. Prod., V305, Article No.127098, } \\
\text { doi:10.1016/j.jclepro.2021.127098 }\end{array}$ & Article & 2 & [167] \\
\hline 44 & $\begin{array}{l}\text { Nam E., 2021, J. Clean. Prod., V300, Article No.126962, } \\
\text { doi:10.1016/j.jclepro.2021.126962 }\end{array}$ & Article & 2 & [168] \\
\hline 45 & $\begin{array}{l}\text { Wang S.Y., 2021, Build. Environ., V195, Article No. 107777, } \\
\text { doi:10.1016/j.buildenv.2021.107777 }\end{array}$ & Article & 2 & [169] \\
\hline 46 & $\begin{array}{l}\text { Malek M., 2021, Materials, V14, Article No.1888, } \\
\text { doi:10.3390/ma14081888 }\end{array}$ & Article & 2 & [170] \\
\hline 47 & $\begin{array}{c}\text { Zhang T., 2021, Resour. Conserv. Recy., V164, } \\
\text { Article No.105124, } \\
\text { doi:10.1016/j.resconrec.2020.105124 }\end{array}$ & Article & 2 & [171] \\
\hline 48 & $\begin{array}{l}\text { Lin J., 2019, Sci. Rep-uk, V9, Article No. 16095, } \\
\text { doi:10.1038/s41598-019-52653-0 }\end{array}$ & Article & 2 & [172] \\
\hline 49 & $\begin{array}{l}\text { Shimoda Y., 2021, Appl. Energ., V303, Article No. 117510, } \\
\text { doi:10.1016/j.apenergy.2021.117510 }\end{array}$ & Article & 1 & [173] \\
\hline 50 & $\begin{array}{l}\text { Li W., 2021, Therm. Sci. Eng. Prog., V25, } \\
\text { Article No. 101033, } \\
\text { doi:10.1016/j.tsep.2021.101033 }\end{array}$ & Article & 1 & [174] \\
\hline 51 & $\begin{array}{l}\text { Tang B.J., 2021, Appl. Energ., V298, Article No. 117213, } \\
\text { doi:10.1016/j.apenergy.2021.117213 }\end{array}$ & Article & 1 & [12] \\
\hline 52 & $\begin{array}{l}\text { Edelenbosch O.Y., 2021, Technol. Forecast Soc. Change, } \\
\text { V170, Article No. } \\
\text { 120887, doi:10.1016/j.techfore.2021.120887 }\end{array}$ & Article & 1 & [175] \\
\hline 53 & $\begin{array}{l}\text { Tang B.J., 2021, J. Clean. Prod., V 307, Article No. 127206, } \\
\text { doi:10.1016/j.jclepro.2021.127206 }\end{array}$ & Article & 1 & [176] \\
\hline 54 & $\begin{array}{c}\text { Zhao Y.J., 2021, Renew. Sust. Energ. Rev., V 145, } \\
\text { Article No. 111091, } \\
\text { doi:10.1016/j.rser.2021.111091 }\end{array}$ & Article & 1 & [177] \\
\hline 55 & $\begin{array}{c}\text { Yue H., 2021, J. Clean. Prod., V 301, Article No. 126978, } \\
\text { doi:10.1016/j.jclepro.2021.126978 }\end{array}$ & Article & 1 & [178] \\
\hline 56 & $\begin{array}{l}\text { Nibedita B., 2021, Environ. Sci. Pollut. R., V28, } \\
\text { P56938-56954, } \\
\text { doi:10.1007/s11356-021-14642-7 }\end{array}$ & Article & 1 & [179] \\
\hline 57 & $\begin{array}{l}\text { Cao X.Y., 2021, Energ. Buildings, V 236, Article No. 110767, } \\
\text { doi:10.1016/j.enbuild.2021.110767 }\end{array}$ & Article & 1 & [180] \\
\hline 58 & $\begin{array}{l}\text { Meuer J., 2021, Energ. Buildings, V 235, Article No. 110710, } \\
\text { doi:10.1016/j.enbuild.2020.110710 }\end{array}$ & Article & 1 & [181] \\
\hline 59 & $\begin{array}{l}\text { Cheng S.L., 2021, Environ. Sci. Technol., V55, P 813-822, } \\
\text { doi:10.1021/acs.est.0c04026 }\end{array}$ & Article & 1 & [182] \\
\hline 60 & $\begin{array}{c}\text { Shi Q.W., 2020, Sustainability, V12, Article No.10432, } \\
\text { doi:10.3390/su122410432 }\end{array}$ & Article & 1 & [183] \\
\hline 61 & $\begin{array}{l}\text { Zhang L.H., 2020, J. Clean. Prod., V272, Article No. 122760, } \\
\text { doi:10.1016/j.jclepro.2020.122760 }\end{array}$ & Article & 1 & [184] \\
\hline 62 & $\begin{array}{c}\text { Liu Y.S., 2022, Renew. Sust. Energ. Rev., V154, } \\
\text { Article No. 111811, } \\
\text { doi:10.1016/j.rser.2021.111811 }\end{array}$ & Article & 0 & [185] \\
\hline
\end{tabular}


Table A1. Count.

\begin{tabular}{|c|c|c|c|c|}
\hline \multirow{2}{*}{ Rank } & Citing Articles & \multirow{2}{*}{ Type } & \multirow{2}{*}{ Times Cited } & \multirow{2}{*}{ Reference } \\
\hline & Author, Year, Journal, Volume, Page/Article Number, doi & & & \\
\hline 63 & $\begin{array}{l}\text { Li K., 2022, Appl. Energ., V306, Article No. 118098, } \\
\text { doi:10.1016/j.apenergy.2021.118098 }\end{array}$ & Article & 0 & [117] \\
\hline 64 & $\begin{array}{l}\text { Meng M., 2022, Energy, V239, Article No. 121912, } \\
\text { doi:10.1016/j.energy.2021.121912 }\end{array}$ & Article & 0 & [186] \\
\hline 65 & $\begin{array}{l}\text { Yamaguchi Y., 2022, Appl. Energ., V306, Article No. 117907, } \\
\text { doi:10.1016/j.apenergy.2021.117907 }\end{array}$ & Article & 0 & [187] \\
\hline 66 & $\begin{array}{c}\text { Al Shawa B., 2021, Energ. Buildings, V254, } \\
\text { Article No.111634, } \\
\text { doi:10.1016/j.enbuild.2021.111634 }\end{array}$ & Review & 0 & [188] \\
\hline 67 & $\begin{array}{l}\text { Lin J., 2021, Appl. Energ., V304, Article No. 117741, } \\
\text { doi:10.1016/j.apenergy.2021.117741 }\end{array}$ & Article & 0 & [189] \\
\hline 68 & $\begin{array}{l}\text { Zhang S.C., 2021, Energ. Policy, V159, Article No. 112661, } \\
\text { doi:10.1016/j.enpol.2021.112661 }\end{array}$ & Article & 0 & [190] \\
\hline 69 & $\begin{array}{l}\text { Su C., 2021, Energies, V14, Article No. 7461, } \\
\text { doi:10.3390/en14227461 }\end{array}$ & Article & 0 & [191] \\
\hline 70 & $\begin{array}{l}\text { Zhong X.Y., 2021, Nat. Commun., V12, Article No. 6126, } \\
\text { doi:10.1038/s41467-021-26212-z }\end{array}$ & Article & 0 & [192] \\
\hline 71 & $\begin{array}{c}\text { Fan G.J., 2021, Front. Earth Sci., V9, Article No. 694729, } \\
\text { doi:10.3389/ feart.2021.694729 }\end{array}$ & Article & 0 & [193] \\
\hline 72 & $\begin{array}{l}\text { Jia J.J., 2021, Energ. Effic., V14, Article No. 65, } \\
\text { doi:10.1007/s12053-021-09974-9 }\end{array}$ & Article & 0 & [194] \\
\hline 73 & $\begin{array}{c}\text { Liu J.L., 2021, Renew. Sust. Energ. Rev., V149, } \\
\text { Article No. 111336, } \\
\text { doi:10.1016/j.rser.2021.111336 }\end{array}$ & Article & 0 & [195] \\
\hline 74 & $\begin{array}{l}\text { Wang L., 2021, Appl. Energ., V299, Article No. 117303, } \\
\text { doi:10.1016/j.apenergy.2021.117303 }\end{array}$ & Article & 0 & [196] \\
\hline 75 & $\begin{array}{l}\text { Zhang S.C., 2021, Adv. Clim. Chang. Res., V12, P734-743, } \\
\text { doi:10.1016/j.accre.2021.07.004 }\end{array}$ & Article & 0 & [197] \\
\hline 76 & $\begin{array}{l}\text { Chi F.A., 2021, Sol. Energy, V225, P1026-1047, } \\
\text { doi:10.1016/j.solener.2021.08.020 }\end{array}$ & Article & 0 & [198] \\
\hline 77 & $\begin{array}{l}\text { Liu Q.C., 2021, J. Ind. Ecol., } \\
\text { doi:10.1111/jiec.13182 }\end{array}$ & Article & 0 & [199] \\
\hline 78 & $\begin{array}{l}\text { Yang X.Y., 2021, Int. J. Life Cycle Ass., V26, P1721-1734, } \\
\text { doi:10.1007/s11367-021-01960-8 }\end{array}$ & Article & 0 & [200] \\
\hline 79 & $\begin{array}{l}\text { Yue H., 2021, Energ. Effic., V14, Article No. 60, } \\
\text { doi:10.1007/s12053-021-09979-4 }\end{array}$ & Review & 0 & [201] \\
\hline 80 & $\begin{array}{l}\text { Vand B., 2021, Energ. Convers. Manage., } \\
\text { Article No. 114178, } \\
\text { doi:10.1016/j.enconman.2021.114178 }\end{array}$ & Article & 0 & [202] \\
\hline 81 & $\begin{array}{l}\text { Jiang J.J., 2021, Environ. Sci. Technol., V55, P7225-7236, } \\
\text { doi:10.1021/acs.est.0c06952 }\end{array}$ & Article & 0 & [203] \\
\hline 82 & $\begin{array}{l}\text { Tong H., 2019, J. Clean. Prod., V45, P10989-10996, } \\
\text { doi:10.1039/d1nj01464a }\end{array}$ & Review & 0 & [204] \\
\hline 83 & $\begin{array}{l}\text { Gou S.W., 2021, Arab. J. Geosci., V14, Article No. 803, } \\
\text { doi:10.1007/s12517-021-07104-4 }\end{array}$ & Article & 0 & [205] \\
\hline
\end{tabular}


Table A1. Count.

\begin{tabular}{ccccc}
\hline \multirow{2}{*}{ Rank } & Citing Articles & Type & Times Cited & Reference \\
\cline { 2 - 3 } 84 & Author, Year, Journal, Volume, Page/Article Number, doi & & 0 \\
\hline \multirow{2}{*}{85} & $\begin{array}{c}\text { Fan G.J., 2021, Oil Gas Sci. Technol., V76, Article No. 30, } \\
\text { doi:10.2516/ogst/2021007 }\end{array}$ & Article & [206] \\
\hline $\begin{array}{c}\text { Yue H., 2021, Appl. Energ., V282, Article No. 116241, } \\
\text { doi:10.1016/j.apenergy.2020.116241 }\end{array}$ & Article & 0 \\
\hline
\end{tabular}

Note: Highly cited paper.

\section{References}

1. Chang, C.-C. A multivariate causality test of carbon dioxide emissions, energy consumption and economic growth in China. Appl. Energy 2010, 87, 3533-3537. [CrossRef]

2. Zuo, J.; Zhao, Z.-Y. Green building research-current status and future agenda: A review. Renew. Sustain. Energy Rev. 2014, 30, 271-281. [CrossRef]

3. Wan, K.K.W.; Li, D.H.W.; Pan, W.; Lam, J.C. Impact of climate change on building energy use in different climate zones and mitigation and adaptation implications. Appl. Energy 2012, 97, 274-282. [CrossRef]

4. Santamouris, M. Innovating to zero the building sector in Europe: Minimising the energy consumption, eradication of the energy poverty and mitigating the local climate change. Sol. Energy 2016, 128, 61-94. [CrossRef]

5. Zhao, X.B.; Zuo, J.; Wu, G.D.; Huang, C. A bibliometric review of green building research 2000-2016. Archit. Sci. Rev. 2019, 62, 74-88. [CrossRef]

6. Global Alliance for Buildings and Construction. Towards a Zero-Emission, Efficient and Resilient Buildings and Construction Sector. 2019. Available online: https://www.worldgbc.org/news-media/2019-global-status-report-buildings-and-construction (accessed on 30 November 2021).

7. Ma, M.; Ma, X.; Cai, W.; Cai, W. Low carbon roadmap of residential building sector in China: Historical mitigation and prospective peak. Appl. Energy 2020, 273, 115247. [CrossRef]

8. Lu, H.; Ma, X.; Ma, M.; Zhu, S. Energy price prediction using data-driven models: A decade review. Comput. Sci. Rev. 2021, 39, 100356. [CrossRef]

9. Eom, J.; Clarke, L.; Kim, S.H.; Kyle, P.; Patel, P. China's building energy demand: Long-term implications from a detailed assessment. Energy 2012, 46, 405-419. [CrossRef]

10. Pérez-Lombard, L.; Ortiz, J.; Pout, C. A review on buildings energy consumption information. Energy Build. 2008, 40, 394-398. [CrossRef]

11. Li, X.; Dong, M.; Jiang, D.; Li, S.; Shang, Y. The effect of surface roughness on normal restitution coefficient, adhesion force and friction coefficient of the particle-wall collision. Powder Technol. 2020, 362, 17-25. [CrossRef]

12. Tang, B.-J.; Guo, Y.-Y.; Yu, B.; Harvey, L.D.D. Pathways for decarbonizing China's building sector under global warming thresholds. Appl. Energy 2021, 298, 117213. [CrossRef]

13. Wang, M.; Wang, P.; Wu, L.; Yang, R.-P.; Feng, X.-Z.; Zhao, M.-X.; Du, X.-L.; Wang, Y.-J. Criteria for assessing carbon emissions peaks at provincial level in China. Adv. Clim. Chang. Res. 2021, 13, 131-137. [CrossRef]

14. Wu, X.; Tian, Z.; Guo, J. A review of the theoretical research and practical progress of carbon neutrality. Sustain. Oper. Comput. 2022, 3, 54-66. [CrossRef]

15. Zou, C.; Xue, H.; Xiong, B.; Zhang, G.; Pan, S.; Jia, C.; Wang, Y.; Ma, F.; Sun, Q.; Guan, C.; et al. Connotation, innovation and vision of "carbon neutrality". Nat. Gas Ind. B 2021, 8, 523-537. [CrossRef]

16. UNFCC. Copenhagen Accord. In Proceedings of the United Nations Climate Change Conference in Copenhagen, Copenhagen, Denmark, 7-18 December 2009.

17. Berardi, U. Building Energy Consumption in US, EU, and BRIC Countries. Procedia Eng. 2015, 118, 128-136. [CrossRef]

18. Fang, K.; Li, C.; Tang, Y.; He, J.; Song, J. China's pathways to peak carbon emissions: New insights from various industrial sectors. Appl. Energy 2022, 306, 118039. [CrossRef]

19. Qi, Y.; Stern, N.; He, J.-K.; Lu, J.-Q.; Liu, T.-L.; King, D.; Wu, T. The policy-driven peak and reduction of China's carbon emissions. Adv. Clim. Chang. Res. 2020, 11, 65-71. [CrossRef]

20. Broadstock, D.; Ji, Q.; Managi, S.; Zhang, D. Pathways to carbon neutrality: Challenges and opportunities. Resour. Conserv. Recycl. 2021, 169, 105472. [CrossRef]

21. Mallapaty, S. How China could be carbon neutral by mid-century. Nature 2020, 586, 482-483. [CrossRef]

22. The White House. Administration Announces U.S. Emission Target for Copenhagen; President to Attend Copenhagen Climate Talks; Office of the Press Secretary, The White House: Washington, DC, USA, 2009.

23. HM Government. Climate Change Act 2008; The Stationery Office Limited,: London, UK, 2008.

24. You, F.; Hu, D.; Zhang, H.; Guo, Z.; Zhao, Y.; Wang, B.; Yuan, Y. Carbon emissions in the life cycle of urban building system in China-A case study of residential buildings. Ecol. Complex. 2011, 8, 201-212. [CrossRef] 
25. Zhang, Y.; Yan, D.; Hu, S.; Guo, S. Modelling of energy consumption and carbon emission from the building construction sector in China, a process-based LCA approach. Energy Policy 2019, 134, 110949. [CrossRef]

26. Danatzko, J.M.; Sezen, H.; Chen, Q. Sustainable design and energy consumption analysis for structural components. J. Green Build. 2013, 8, 120-135. [CrossRef]

27. Sozer, H. Improving energy efficiency through the design of the building envelope. Build. Environ. 2010, 45, 2581-2593. [CrossRef]

28. Lam, P.T.I.; Chan, E.H.W.; Poon, C.S.; Chau, C.K.; Chun, K.P. Factors affecting the implementation of green specifications in construction. J. Environ. Manag. 2010, 91, 654-661. [CrossRef]

29. Chen, M.; Ma, M.; Lin, Y.; Ma, Z.; Li, K. Carbon Kuznets curve in China's building operations: Retrospective and prospective trajectories. Sci. Total Environ. 2022, 803, 150104. [CrossRef]

30. Ma, M.; Pan, T.; Ma, Z. Examining the Driving Factors of Chinese Commercial Building Energy Consumption from 2000 to 2015 : A STIRPAT Model Approach. J. Eng. Sci. Technol. Rev. 2017, 10, 28-34. [CrossRef]

31. Yan, R.; Ma, M.; Pan, T. Estimating energy savings in Chinese residential buildings from 2001 to 2015: A decomposition analysis. J. Eng. Sci. Technol. Rev. 2017, 10, 107-113. [CrossRef]

32. Ma, M.; Cai, W.; Cai, W. Carbon abatement in China's commercial building sector: A bottom-up measurement model based on Kaya-LMDI methods. Energy 2018, 165, 350-368. [CrossRef]

33. Ma, M.; Cai, W. Do commercial building sector-derived carbon emissions decouple from the economic growth in Tertiary Industry? A case study of four municipalities in China. Sci. Total Environ. 2019, 650, 822-834. [CrossRef]

34. Hong, T.; Piette, M.A.; Chen, Y.; Lee, S.H.; Taylor-Lange, S.C.; Zhang, R.; Sun, K.; Price, P. Commercial building energy saver: An energy retrofit analysis toolkit. Appl. Energy 2015, 159, 298-309. [CrossRef]

35. Zhang, S.; Xiang, X.; Ma, Z.; Ma, M.; Zou, C. Carbon neutral roadmap of commercial building operations by mid-century: Lessons from China. Buildings 2021, 11, 510. [CrossRef]

36. Zhang, S.; Ma, M.; Li, K.; Ma, Z.; Feng, W.; Cai, W. Historical carbon abatement in the commercial building operation: China versus the US. Energy Econ. 2022, 105, 105712. [CrossRef]

37. Tian, Z.; Zhang, S.; Li, H.; Jiang, Y.; Dong, J.; Zhang, B.; Yi, R. Investigations of Nearly (net) Zero Energy Residential Buildings in Beijing. Procedia Eng. 2015, 121, 1051-1057. [CrossRef]

38. Zheng, X.; Wei, C.; Qin, P.; Guo, J.; Yu, Y.; Song, F.; Chen, Z. Characteristics of residential energy consumption in China: Findings from a household survey. Energy Policy 2014, 75, 126-135. [CrossRef]

39. Yao, C.; Chen, C.; Li, M. Analysis of rural residential energy consumption and corresponding carbon emissions in China. Energy Policy 2012, 41, 445-450. [CrossRef]

40. Zhang, L.; Yang, Z.; Chen, B.; Chen, G. Rural energy in China: Pattern and policy. Renew. Energy 2009, 34, 2813-2823. [CrossRef]

41. Zhang, X.; Luo, L.; Skitmore, M. Household carbon emission research: An analytical review of measurement, influencing factors and mitigation prospects. J. Clean. Prod. 2015, 103, 873-883. [CrossRef]

42. Lu, H.; Ma, X.; Ma, M. A hybrid multi-objective optimizer-based model for daily electricity demand prediction considering COVID-19. Energy 2021, 219, 119568. [CrossRef]

43. Cai, W.; Liu, C.; Jia, S.; Chan, F.T.S.; Ma, M.; Ma, X. An emergy-based sustainability evaluation method for outsourcing machining resources. J. Clean. Prod. 2020, 245, 118849. [CrossRef]

44. Ma, M.; Yan, R.; Du, Y.; Ma, X.; Cai, W.; Xu, P. A methodology to assess China's building energy savings at the national level: An IPAT-LMDI model approach. J. Clean. Prod. 2017, 143, 784-793. [CrossRef]

45. Ahmad, A.S.; Hassan, M.Y.; Abdullah, M.P.; Rahman, H.A.; Hussin, F.; Abdullah, H.; Saidur, R. A review on applications of ANN and SVM for building electrical energy consumption forecasting. Renew. Sustain. Energy Rev. 2014, 33, 102-109. [CrossRef]

46. Fadzli Haniff, M.; Selamat, H.; Yusof, R.; Buyamin, S.; Sham Ismail, F. Review of HVAC scheduling techniques for buildings towards energy-efficient and cost-effective operations. Renew. Sustain. Energy Rev. 2013, 27, 94-103. [CrossRef]

47. Huseien, G.F.; Shah, K.W. A review on $5 \mathrm{G}$ technology for smart energy management and smart buildings in Singapore. Energy AI 2022, 7, 100116. [CrossRef]

48. Tetteh, E.K.; Amankwa, M.O.; Yeboah, C.; Amankwa, M.O. Emerging carbon abatement technologies to mitigate energy-carbon footprint- a review. Clean. Mater. 2021, 2, 100020. [CrossRef]

49. Wang, F.; Harindintwali, J.D.; Yuan, Z.; Wang, M.; Wang, F.; Li, S.; Yin, Z.; Huang, L.; Fu, Y.; Li, L.; et al. Technologies and perspectives for achieving carbon neutrality. Innovation 2021, 2, 100180. [CrossRef]

50. Xiang, X.; Ma, X.; Ma, Z.; Ma, M.; Cai, W. Python-LMDI: A tool for index decomposition analysis to building carbon emissions. Buildings 2022, 12, 83. [CrossRef]

51. Yang, Z.; Liu, B.; Zhao, H.B. Energy saving in building construction in China: A review. Int. J. Green Energy 2004, 1, $209-225$. [CrossRef]

52. Lu, M.; Lai, J. Review on carbon emissions of commercial buildings. Renew. Sustain. Energy Rev. 2020, 119, 109545. [CrossRef]

53. GhaffarianHoseini, A.; Dahlan, N.D.; Berardi, U.; GhaffarianHoseini, A.; Makaremi, N.; GhaffarianHoseini, M. Sustainable energy performances of green buildings: A review of current theories, implementations and challenges. Renew. Sustain. Energy Rev. 2013, 25, 1-17. [CrossRef]

54. Han, S.; Yao, R.; Li, N. The development of energy conservation policy of buildings in China: A comprehensive review and analysis. J. Build. Eng. 2021, 38, 102229. [CrossRef] 
55. Verma, P.; Kumari, T.; Raghubanshi, A.S. Energy emissions, consumption and impact of urban households: A review. Renew. Sustain. Energy Rev. 2021, 147, 111210. [CrossRef]

56. Wang, Y.; Mauree, D.; Sun, Q.; Lin, H.; Scartezzini, J.L.; Wennersten, R. A review of approaches to low-carbon transition of high-rise residential buildings in China. Renew. Sustain. Energy Rev. 2020, 131, 109990. [CrossRef]

57. Akbarnezhad, A.; Xiao, J.Z. Estimation and minimization of embodied carbon of buildings: A review. Buildings 2017, 7, 5. [CrossRef]

58. Ma, M.; Cai, W.; Wu, Y. China act on the energy efficiency of civil buildings (2008): A decade review. Sci. Total Environ. 2019, 651, 42-60. [CrossRef]

59. Chau, C.K.; Leung, T.M.; Ng, W.Y. A review on Life Cycle Assessment, Life Cycle Energy Assessment and Life Cycle Carbon Emissions Assessment on buildings. Appl. Energy 2015, 143, 395-413. [CrossRef]

60. Pouris, A.; Pouris, A. Scientometrics of a pandemic: HIV/AIDS research in South Africa and the World. Scientometrics 2011, 86, 541-552. [CrossRef]

61. Archambault, E.; Campbell, D.; Gingras, Y.; Lariviere, V. Comparing of science bibliometric statistics obtained from the Web of Science and Scopus. J. Am. Soc. Inf. Sci. Technol. 2009, 60, 1320-1326. [CrossRef]

62. Singh, V.K.; Singh, P.; Karmakar, M.; Leta, J.; Mayr, P. The journal coverage of Web of Science, Scopus and Dimensions: A comparative analysis. Scientometrics 2021, 126, 5113-5142. [CrossRef]

63. Tan, H.; Li, J.; He, M.; Li, J.; Zhi, D.; Qin, F.; Zhang, C. Global evolution of research on green energy and environmental technologies:A bibliometric study. J. Environ. Manag. 2021, 297, 113382. [CrossRef]

64. Niazi, M.A. CiteSpace: A Practical Guide for Mapping Scientific Literature. Compex Adapt. Syst. Model. 2016, 4, 3. [CrossRef]

65. Li, X.; Wu, P.; Shen, G.Q.; Wang, X.; Teng, Y. Mapping the knowledge domains of Building Information Modeling (BIM): A bibliometric approach. Autom. Constr. 2017, 84, 195-206. [CrossRef]

66. Morgan, J. Paris COP 21: Power that Speaks the Truth? Globalizations 2016, 13, 943-951. [CrossRef]

67. Torstad, V.H. Participation, ambition and compliance: Can the Paris Agreement solve the effectiveness trilemma? Environ. Polit. 2020, 29, 761-780. [CrossRef]

68. Andresen, S.; Skjaeseth, J.B.; Jevnaker, T.; Wettestad, J. The Paris Agreement: Consequences for the EU and Carbon Markets? Politics Gov. 2016, 4, 188-196. [CrossRef]

69. The Climate Ambition Summit 2020 celebrated this year five years of the adoption of the Paris Agreement. Future Food 2020, 8, 76

70. Ma, M.D.; Yan, R.; Cai, W.G. Energy savings evaluation in public building sector during the 10th-12th FYP periods of China: An extended LMDI model approach. Nat. Hazards 2018, 92, 429-441. [CrossRef]

71. State_Council. “Thirteenth Five-Year Plan” Work Plan for Controlling Greenhouse Gas Emissions, Beijing, China. 2016. Available online: http:/ / www.gov.cn/zhengce/content/2016-11/04/content_5128619.htm (accessed on 16 August 2021). (In Chinese)

72. Chen, C.M.; Hu, Z.G.; Liu, S.B.; Tseng, H. Emerging trends in regenerative medicine: A scientometric analysis in CiteSpace. Expert Opin. Biol. Ther. 2012, 12, 593-608. [CrossRef]

73. Macintosh, A. Keeping warming within the $2{ }^{\circ} \mathrm{C}$ limit after Copenhagen. Energy Policy 2010, 38, 2964-2975. [CrossRef]

74. Small, H. Cocitation in scientific literature-New measure of relationship between 2 documents. J. Am. Soc. Inf. Sci. 1973, 24, 265-269. [CrossRef]

75. Zhou, N.; Khanna, N.; Feng, W.; Ke, J.; Levine, M. Scenarios of energy efficiency and $\mathrm{CO}_{2}$ emissions reduction potential in the buildings sector in China to year 2050. Nat. Energy 2018, 3, 978-984. [CrossRef]

76. Ma, M.; Ma, X.; Cai, W.; Cai, W. Carbon-dioxide mitigation in the residential building sector: A household scale-based assessment. Energy Convers. Manag. 2019, 198, 111915. [CrossRef]

77. Liang, Y.; Cai, W.; Ma, M. Carbon dioxide intensity and income level in the Chinese megacities' residential building sector: Decomposition and decoupling analyses. Sci. Total Environ. 2019, 677, 315-327. [CrossRef] [PubMed]

78. Ma, M.; Cai, W. What drives the carbon mitigation in Chinese commercial building sector? Evidence from decomposing an extended Kaya identity. Sci. Total Environ. 2018, 634, 884-899. [CrossRef] [PubMed]

79. Tan, X.; Lai, H.; Gu, B.; Zeng, Y.; Li, H. Carbon emission and abatement potential outlook in China's building sector through 2050. Energy Policy 2018, 118, 429-439. [CrossRef]

80. Fargione, J.; Hill, J.; Tilman, D.; Polasky, S.; Hawthorne, P. Land clearing and the biofuel carbon debt. Science 2008, 319, 1235-1238. [CrossRef]

81. Sartori, I.; Napolitano, A.; Voss, K. Net zero energy buildings: A consistent definition framework. Energy Build. 2012, 48, $220-232$. [CrossRef]

82. Lin, B.; Liu, H. CO $\mathrm{CO}_{2}$ emissions of China's commercial and residential buildings: Evidence and reduction policy. Build. Environ. 2015, 92, 418-431. [CrossRef]

83. McNeil, M.A.; Feng, W.; de la Rue du Can, S.; Khanna, N.Z.; Ke, J.; Zhou, N. Energy efficiency outlook in China's urban buildings sector through 2030. Energy Policy 2016, 97, 532-539. [CrossRef]

84. Harvey, L.D.D. Reducing energy use in the buildings sector: Measures, costs, and examples. Energy Effic. 2009, 2, 139-163. [CrossRef]

85. Chen, X.; Shuai, C.; Wu, Y.; Zhang, Y. Analysis on the carbon emission peaks of China's industrial, building, transport, and agricultural sectors. Sci. Total Environ. 2020, 709, 135768. [CrossRef] 
86. Huang, Y.; Liao, C.; Zhang, J.; Guo, H.; Zhou, N.; Zhao, D. Exploring potential pathways towards urban greenhouse gas peaks: A case study of Guangzhou, China. Appl. Energy 2019, 251, 113369. [CrossRef]

87. Wang, J.; Cai, H.; Li, L. Energy demand and carbon emission peak forecasting of Beijing based on leap energy simulation method. Glob. Nest. J. 2020, 22, 565-569. [CrossRef]

88. Li, B.; Han, S.; Wang, Y.; Wang, Y.; Li, J.; Wang, Y. Feasibility assessment of the carbon emissions peak in China's construction industry: Factor decomposition and peak forecast. Sci. Total Environ. 2020, 706, 135716. [CrossRef] [PubMed]

89. Wang, Y.; Su, X.L.; Qi, L.; Shang, P.P.; Xu, Y.H. Feasibility of peaking carbon emissions of the power sector in China's eight regions: Decomposition, decoupling, and prediction analysis. Environ. Sci. Pollut. Res. 2019, 26, 29212-29233. [CrossRef]

90. Jiang, J.; Ye, B.; Liu, J. Research on the peak of $\mathrm{CO}_{2}$ emissions in the developing world: Current progress and future prospect. Appl. Energy 2019, 235, 186-203. [CrossRef]

91. Berardi, U. A cross-country comparison of the building energy consumptions and their trends. Resour. Conserv. Recycl. 2017, 123, 230-241. [CrossRef]

92. Guo, S.; Yan, D.; Hu, S.; Zhang, Y. Modelling building energy consumption in China under different future scenarios. Energy 2021, 214, 119063. [CrossRef]

93. Peng, C.; Yan, D.; Guo, S.; Hu, S.; Jiang, Y. Building energy use in China: Ceiling and scenario. Energy Build. 2015, 102, 307-316. [CrossRef]

94. Gil, L.; Bernardo, J. An approach to energy and climate issues aiming at carbon neutrality. Renew. Energy Focus 2020, 33, 37-42. [CrossRef]

95. United Nations. Paris Agreement-Status of Ratification. 2018. Available online: https://unfccc.int/process/the-paris-agreement/ status-of-ratification (accessed on 26 August 2021).

96. Yu, S.; Eom, J.; Evans, M.; Clarke, L. A long-term, integrated impact assessment of alternative building energy code scenarios in China. Energy Policy 2014, 67, 626-639. [CrossRef]

97. Su, K.; Lee, C.-M. When will China achieve its carbon emission peak? A scenario analysis based on optimal control and the STIRPAT model. Ecol. Indic. 2020, 112, 106138. [CrossRef]

98. Energy Information Administration. Analysis-Energy Sector Highlights. 2020. Available online: https://www.eia.gov/ international/overview/country/IND (accessed on 13 December 2021).

99. RMI, India. Reducing Embodied Carbon Is Key to Meeting India's Climate Targets. 2021. Available online: https://www.eia. gov/consumption/residential/ (accessed on 13 December 2021).

100. Goldemberg, J. The evolution of the energy and carbon intensities of developing countries. Energy Policy 2020, 137, 111060. [CrossRef]

101. De La Peña, L.; Guo, R.; Cao, X.; Ni, X.; Zhang, W. Accelerating the energy transition to achieve carbon neutrality. Resour. Conserv. Recycl. 2022, 177, 105957. [CrossRef]

102. Tan, S.; Yang, J.; Yan, J.; Lee, C.; Hashim, H.; Chen, B. A holistic low carbon city indicator framework for sustainable development. Appl. Energy 2017, 185, 1919-1930. [CrossRef]

103. Chen, L.; Cai, W.; Ma, M. Decoupling or delusion? Mapping carbon emission per capita based on the human development index in Southwest China. Sci. Total Environ. 2020, 741, 138722. [CrossRef]

104. Ma, M.; Cai, W.; Cai, W.; Dong, L. Whether carbon intensity in the commercial building sector decouples from economic development in the service industry? Empirical evidence from the top five urban agglomerations in China. J. Clean. Prod. 2019, 222, 193-205. [CrossRef]

105. Fang, K.; Tang, Y.; Zhang, Q.; Song, J.; Wen, Q.; Sun, H.; Ji, C.; Xu, A. Will China peak its energy-related carbon emissions by 2030? Lessons from 30 Chinese provinces. Appl. Energy 2019, 255, 113852. [CrossRef]

106. Yang, Y.; Li, B.; Yao, R. A method of identifying and weighting indicators of energy efficiency assessment in Chinese residential buildings. Energy Policy 2010, 38, 7687-7697. [CrossRef]

107. Kavgic, M.; Hilliard, T.; Swan, L. Opportunities for Implementation of MPC in Commercial Buildings. Energy Procedia 2015, 78 , 2148-2153. [CrossRef]

108. Xiang, X.; Ma, X.; Ma, Z.; Ma, M. Operational Carbon Change in Commercial Buildings under the Carbon Neutral Goal: A LASSO-WOA Approach. Buildings 2022, 12, 54. [CrossRef]

109. Wu, C.B.; Huang, G.H.; Xin, B.G.; Chen, J.K. Scenario analysis of carbon emissions' anti-driving effect on Qingdao's energy structure adjustment with an optimization model, Part I: Carbon emissions peak value prediction. J. Clean. Prod. 2018, 172, 466-474. [CrossRef]

110. Huang, W.; Li, F.; Cui, S.-H.; Li, F.; Huang, L.; Lin, J.-Y. Carbon Footprint and Carbon Emission Reduction of Urban Buildings: A Case in Xiamen City, China. Procedia Eng. 2017, 198, 1007-1017. [CrossRef]

111. Li, D.; Huang, G.; Zhu, S.; Chen, L.; Wang, J. How to peak carbon emissions of provincial construction industry? Scenario analysis of Jiangsu Province. Renew. Sustain. Energy Rev. 2021, 144, 110953. [CrossRef]

112. Gomi, K.; Shimada, K.; Matsuoka, Y. A low-carbon scenario creation method for a local-scale economy and its application in Kyoto city. Energy Policy 2010, 38, 4783-4796. [CrossRef]

113. Farzaneh, H. Development of a Bottom-up Technology Assessment Model for Assessing the Low Carbon Energy Scenarios in the Urban System. Energy Procedia 2017, 107, 321-326. [CrossRef] 
114. Jing, Q.; Bai, H.; Luo, W.; Cai, B.; Xu, H. A top-bottom method for city-scale energy-related $\mathrm{CO}_{2}$ emissions estimation: A case study of 41 Chinese cities. J. Clean. Prod. 2018, 202, 444-455. [CrossRef]

115. Yang, L.; Ma, Z.; Ma, M.; Xu, Y. Decarbonization, Environmental Regulation, and Economic Boom: An Indicator Assessment Based on the Industrial Waste. Front. Energy Res. 2022, 9, 838852. [CrossRef]

116. National Bureau of Statistics of China. 2020 China Statistical Yearbook; China Statistical Publishing House: Beijing, China, 2020.

117. Li, K.; Ma, M.; Xiang, X.; Feng, W.; Ma, Z.; Cai, W.; Ma, X. Carbon reduction in commercial building operations: A provincial retrospection in China. Appl. Energy 2022, 306, 118098. [CrossRef]

118. Du, Q.; Han, X.; Li, Y.; Li, Z.; Xia, B.; Guo, X. The energy rebound effect of residential buildings: Evidence from urban and rural areas in China. Energy Policy 2021, 153, 112235. [CrossRef]

119. Yang, X.; Jiang, Y.; Yang, M.; Shan, M. Energy and environment in Chinese rural housing: Current status and future perspective. Front. Energy Power Eng. China 2010, 4, 35-46. [CrossRef]

120. Zhuang, Z.; Li, Y.; Chen, B. Thermal storage performance analysis on Chinese kangs. Energy Build. 2009, 41, 452-459. [CrossRef]

121. Tonooka, Y.; Liu, J.; Kondou, Y.; Ning, Y.; Fukasawa, O. A survey on energy consumption in rural households in the fringes of Xian city. Energy Build. 2006, 38, 1335-1342. [CrossRef]

122. Building Energy Research Center of Tsinghua University. 2020 Annual Report on China Building Energy Efficiency; China Architecture and Building Press: Beijing, China, 2020. (In Chinese)

123. MOHURD. To Celebrate the 70th Anniversary of the Founding of the People's Republic of China, the Press Center Held the Second Press Conference. 2019. Available online: https://www.mohurd.gov.cn/xinwen/jsyw/201909/20190926_241997.html (accessed on 13 December 2021). (In Chinese)

124. Zeng, X.; Zhao, Y.; Cheng, Z. Development and research of rural renewable energy management and ecological management information system under the background of beautiful rural revitalization strategy. Sustain. Comput. Inform. Syst. 2021, 30 , 100553. [CrossRef]

125. Li, J.; Chen, C.; Liu, H. Transition from non-commercial to commercial energy in rural China: Insights from the accessibility and affordability. Energy Policy 2019, 127, 392-403. [CrossRef]

126. Hu, X.; Xiang, Y.; Zhang, H.; Lin, Q.; Wang, W.; Wang, H. Active-passive combined energy-efficient retrofit of rural residence with non-benchmarked construction: A case study in Shandong province, China. Energy Rep. 2021, 7, 1360-1373. [CrossRef]

127. Zhuang, Z.; Li, Y.; Chen, B.; Guo, J. Chinese kang as a domestic heating system in rural northern China-A review. Energy Build. 2009, 41, 111-119. [CrossRef]

128. Xiaohua, W.; Zhenmin, F. Rural household energy consumption with the economic development in China: Stages and characteristic indices. Energy Policy 2001, 29, 1391-1397. [CrossRef]

129. Wang, P.; Liu, Q.; Qi, Y. Factors influencing sustainable consumption behaviors: A survey of the rural residents in China. J. Clean. Prod. 2014, 63, 152-165. [CrossRef]

130. Liu, W.; Lustig, W.P.; Li, J. Luminescent inorganic-organic hybrid semiconductor materials for energy-saving lighting applications. EnergyChem 2019, 1, 100008. [CrossRef]

131. Langevin, J.; Harris, C.B.; Reyna, J.L. Assessing the Potential to Reduce U.S. Building $\mathrm{CO}_{2}$ Emissions $80 \%$ by 2050. Joule 2019, 3 , 2403-2424. [CrossRef]

132. Zhang, X.; Ranjith, P.G. Experimental investigation of effects of $\mathrm{CO}_{2}$ injection on enhanced methane recovery in coal seam reservoirs. J. CO2 Util. 2019, 33, 394-404. [CrossRef]

133. Jiang, J.; Ye, B.; Liu, J. Peak of $\mathrm{CO}_{2}$ emissions in various sectors and provinces of China: Recent progress and avenues for further research. Renew. Sustain. Energy Rev. 2019, 112, 813-833. [CrossRef]

134. Zhang, X.; Geng, Y.; Shao, S.; Wilson, J.; Song, X.; You, W. China's non-fossil energy development and its $2030 \mathrm{CO}_{2}$ reduction targets: The role of urbanization. Appl. Energy 2020, 261, 114353. [CrossRef]

135. Khanna, N.; Fridley, D.; Zhou, N.; Karali, N.; Zhang, J.; Feng, W. Energy and $\mathrm{CO}_{2}$ implications of decarbonization strategies for China beyond efficiency: Modeling 2050 maximum renewable resources and accelerated electrification impacts. Appl. Energy 2019, 242, 12-26. [CrossRef]

136. Cao, Z.; Liu, G.; Duan, H.; Xi, F.; Liu, G.; Yang, W. Unravelling the mystery of Chinese building lifetime: A calibration and verification based on dynamic material flow analysis. Appl. Energy 2019, 238, 442-452. [CrossRef]

137. Pan, Y.; Zhang, L. Data-driven estimation of building energy consumption with multi-source heterogeneous data. Appl. Energy 2020, 268, 114965. [CrossRef]

138. Dai, B.; Zhao, X.; Liu, S.; Yang, Q.; Zhong, D.; Hao, Y.; Hao, Y. Energetic, exergetic and exergoeconomic assessment of transcritical $\mathrm{CO}_{2}$ reversible system combined with dedicated mechanical subcooling (DMS) for residential heating and cooling. Energy Convers. Manag. 2020, 209, 112594. [CrossRef]

139. Duan, H.; Wang, D.; Pang, X.; Liu, Y.; Zeng, S. A novel forecasting approach based on multi-kernel nonlinear multivariable grey model: A case report. J. Clean. Prod. 2020, 260, 120929. [CrossRef]

140. Xian, Y.; Yang, K.; Wang, K.; Wei, Y.-M.; Huang, Z. Cost-environment efficiency analysis of construction industry in China: A materials balance approach. J. Clean. Prod. 2019, 221, 457-468. [CrossRef]

141. Wang, Y.; Wu, T.; Li, H.; Skitmore, M.; Su, B. A statistics-based method to quantify residential energy consumption and stock at the city level in China: The case of the Guangdong-Hong Kong-Macao Greater Bay Area cities. J. Clean. Prod. 2020, $251,119637$. [CrossRef] 
142. Li, W.; Xia, X.X.; Li, S. Large-scale evaluation of cascaded adsorption heat pumps based on metal/covalent-organic frameworks. J. Mater. Chem. A 2019, 7, 25010-25019. [CrossRef]

143. Chen, Y.; Yang, C.; Pan, X.; Yan, D. Design and operation optimization of multi-chiller plants based on energy performance simulation. Energy Build. 2020, 222, 110100. [CrossRef]

144. Zhang, S.; Fu, Y.; Yang, X.; Xu, W. Assessment of mid-to-long term energy saving impacts of nearly zero energy building incentive policies in cold region of China. Energy Build. 2021, 241, 110938. [CrossRef]

145. Mata, E.; Korpal, A.K.; Cheng, S.H.; Navarro, J.P.J.; Filippidou, F.; Reyna, J.; Wang, R. A map of roadmaps for zero and low energy and carbon buildings worldwide. Environ. Res. Lett. 2020, 15, 19. [CrossRef]

146. Zhu, W.; Feng, W.; Li, X.; Zhang, Z. Analysis of the embodied carbon dioxide in the building sector: A case of China. J. Clean. Prod. 2020, 269, 122438. [CrossRef]

147. Liu, W.; Chen, C.; Wu, H.; Guo, C.; Chen, Y.; Liu, W.; Cui, Z. Environmental life cycle assessment and techno-economic analysis of domestic hot water systems in China. Energy Convers. Manag. 2019, 199, 111943. [CrossRef]

148. Deb, C.; Schlueter, A. Review of data-driven energy modelling techniques for building retrofit. Renew. Sustain. Energy Rev. 2021, 144, 110990. [CrossRef]

149. Zhang, S.; Xu, W.; Wang, K.; Feng, W.; Athienitis, A.; Hua, G.; Okumiya, M.; Yoon, G.; Cho, D.w.; Iyer-Raniga, U.; et al. Scenarios of energy reduction potential of zero energy building promotion in the Asia-Pacific region to year 2050. Energy 2020, $213,118792$. [CrossRef]

150. Memon, S.; Eames, P.C. Design and development of lead-free glass-metallic vacuum materials for the construction and thermal performance of smart fusion edge-sealed vacuum glazing. Energy Build. 2020, 227, 110430. [CrossRef]

151. Liu, Q.; Ren, J. Research on the building energy efficiency design strategy of Chinese universities based on green performance analysis. Energy Build. 2020, 224, 110242. [CrossRef]

152. Yu, B.; Yang, X.; Zhao, Q.; Tan, J. Causal Effect of Time-Use Behavior on Residential Energy Consumption in China. Ecol. Econ. 2020, 175, 106706. [CrossRef]

153. Ding, C.; Zhou, N. Using Residential and Office Building Archetypes for Energy Efficiency Building Solutions in an Urban Scale: A China Case Study. Energies 2020, 13, 16. [CrossRef]

154. Li, H.; Qiu, P.; Wu, T. The regional disparity of per-capita $\mathrm{CO}_{2}$ emissions in China's building sector: An analysis of macroeconomic drivers and policy implications. Energy Build. 2021, 244, 111011. [CrossRef]

155. Li, H.; Sun, B.; Zhang, C. Capacity design of a distributed energy system based on integrated optimization and operation strategy of exergy loss reduction. Energy Convers. Manag. 2021, 231, 113648. [CrossRef]

156. Liu, P.; Lin, B.; Zhou, H.; Wu, X.; Little, J.C. $\mathrm{CO}_{2}$ emissions from urban buildings at the city scale: System dynamic projections and potential mitigation policies. Appl. Energy 2020, 277, 115546. [CrossRef]

157. Zhang, L.; Ma, X.; Wang, Y.; Song, R.; Li, J.; Yuan, W.; Zhang, S. The increasing district heating energy consumption of the building sector in China: Decomposition and decoupling analysis. J. Clean. Prod. 2020, 271, 122696. [CrossRef]

158. Mathew, D.; Naidu, R.C. Investigation of single-stage transformerless buck-boost microinverters. IET Power Electron. 2020, 13, 1487-1499. [CrossRef]

159. Li, L.; Cao, X.; Wang, P. Optimal coordination strategy for multiple distributed energy systems considering supply, demand, and price uncertainties. Energy 2021, 227, 120460. [CrossRef]

160. Mahapatra, B.; Irfan, M. Asymmetric impacts of energy efficiency on carbon emissions: A comparative analysis between developed and developing economies. Energy 2021, 227, 120485. [CrossRef]

161. Nematchoua, M.K.; Asadi, S.; Reiter, S. Influence of energy mix on the life cycle of an eco-neighborhood, a case study of 150 countries. Renew. Energy 2020, 162, 81-97. [CrossRef]

162. Levesque, A.; Pietzcker, R.C.; Baumstark, L.; Luderer, G. Deep decarbonisation of buildings energy services through demand and supply transformations in a 1.5 degrees $C$ scenario. Environ. Res. Lett. 2021, 16, 15. [CrossRef]

163. Yan, B.; Hao, F.; Meng, X. When artificial intelligence meets building energy efficiency, a review focusing on zero energy building Artif. Intell. Rev. 2021, 54, 2193-2220. [CrossRef]

164. Shi, Q.W.; Gao, J.X.; Wang, X.; Ren, H.; Cai, W.G.; Wei, H.F. Temporal and Spatial Variability of Carbon Emission Intensity of Urban Residential Buildings: Testing the Effect of Economics and Geographic Location in China. Sustainability 2020, 12, 23. [CrossRef]

165. Wu, W.; Zhang, W.; Benner, J.; Malkawi, A. Critical evaluation of analytical methods for thermally activated building systems. Renew. Sustain. Energy Rev. 2020, 117, 109516. [CrossRef]

166. Yu, L.; Qin, S.Q.; Zhang, M.; Shen, C.; Jiang, T.; Guan, X.H. A Review of Deep Reinforcement Learning for Smart Building Energy Management. IEEE Internet Things J. 2021, 8, 12046-12063. [CrossRef]

167. Zhong, X.; Hu, M.; Deetman, S.; Rodrigues, J.F.D.; Lin, H.-X.; Tukker, A.; Behrens, P. The evolution and future perspectives of energy intensity in the global building sector 1971-2060. J. Clean. Prod. 2021, 305, 127098. [CrossRef]

168. Nam, E.; Jin, T. Mitigating carbon emissions by energy transition, energy efficiency, and electrification: Difference between regulation indicators and empirical data. J. Clean. Prod. 2021, 300, 126962. [CrossRef]

169. Wang, S.; Liu, Y.; Cao, Q.; Li, H.; Yu, Y.; Yang, L. Applicability of passive design strategies in China promoted under global warming in past half century. Build. Environ. 2021, 195, 107777. [CrossRef] 
170. Malek, M.; Jackowski, M.; Lasica, W.; Kadela, M. Influence of Polypropylene, Glass and Steel Fiber on the Thermal Properties of Concrete. Materials 2021, 14, 18. [CrossRef]

171. Zhang, T.; Tan, Q.; Zhang, S.; Zhang, T.; Zhang, W. A participatory methodology for characterizing and prescribing water-energyfood nexus based on improved casual loop diagrams. Resour. Conserv. Recycl. 2021, 164, 105124. [CrossRef]

172. Lin, J.; Khanna, N.; Liu, X.; Teng, F.; Wang, X. China's Non- $\mathrm{CO}_{2}$ Greenhouse Gas Emissions: Future Trajectories and Mitigation Options and Potential. Sci. Rep. 2019, 9, 10. [CrossRef] [PubMed]

173. Shimoda, Y.; Sugiyama, M.; Nishimoto, R.; Momonoki, T. Evaluating decarbonization scenarios and energy management requirement for the residential sector in Japan through bottom-up simulations of energy end-use demand in 2050. Appl. Energy 2021, 303, 117510. [CrossRef]

174. Li, W.; Liu, Z.; Li, S. The optimal step locations for high-performance adsorption heat pumps under various working conditions. Therm. Sci. Eng. Prog. 2021, 25, 101033. [CrossRef]

175. Edelenbosch, O.Y.; Rovelli, D.; Levesque, A.; Marangoni, G.; Tavoni, M. Long term, cross-country effects of buildings insulation policies. Technol. Forecast. Soc. Chang. 2021, 170, 120887. [CrossRef]

176. Tang, B.; Zou, Y.; Yu, B.; Guo, Y.; Zhao, G. Clean heating transition in the building sector: The case of Northern China. J. Clean. Prod. 2021, 307, 127206. [CrossRef]

177. Zhao, Y.J.; Fan, G.J.; Song, K.P.; Li, Y.L.; Chen, H.; Sun, H. The experimental research for reducing the minimum miscibility pressure of carbon dioxide miscible flooding. Renew. Sust. Energ. Rev. 2021, 145, 11. [CrossRef]

178. Yue, H.; Worrell, E.; Crijns-Graus, W.; Zhang, S. The potential of industrial electricity savings to reduce air pollution from coal-fired power generation in China. J. Clean. Prod. 2021, 301, 126978. [CrossRef]

179. Nibedita, B.; Irfan, M. The role of energy efficiency and energy diversity in reducing carbon emissions: Empirical evidence on the long-run trade-off or synergy in emerging economies. Environ. Sci. Pollut. Res. 2021, 28, 56938-56954. [CrossRef]

180. Cao, X.; Yao, R.; Ding, C.; Zhou, N.; Yu, W.; Yao, J.; Xiong, J.; Xu, Q.; Pan, L.; Li, B. Energy-quota-based integrated solutions for heating and cooling of residential buildings in the Hot Summer and Cold Winter zone in China. Energy Build. 2021, $236,110767$. [CrossRef]

181. Meuer, J.; Lamaro, F.; Vetterli, N. Embedding energy optimization in organizations: A case study of a Swiss decentralized renewable energy system. Energy Build. 2021, 235, 110710. [CrossRef]

182. Cheng, S.L.; Fan, W.; Meng, F.X.; Chen, J.D.; Liang, S.; Song, M.L.; Liu, G.Y.; Casazza, M. Potential Role of Fiscal Decentralization on Interprovincial Differences in $\mathrm{CO}_{2}$ Emissions in China. Environ. Sci. Technol. 2021, 55, 813-822. [CrossRef] [PubMed]

183. Shi, Q.W.; Ren, H.; Cai, W.G.; Gao, J.X. How to Set the Proper $\mathrm{CO}_{2}$ Reduction Targets for the Provincial Building Sector of China? Sustainability 2020, 12, 10432. [CrossRef]

184. Zhang, L.; Song, G.; Ma, X.; Zhan, C.; Zhang, S. Decarbonising residential building energy towards achieving the intended nationally determined contribution at subnational level under uncertainties. J. Clean. Prod. 2020, 272, 122760. [CrossRef]

185. Liu, Y.; Wang, Y.; Shi, C.; Zhang, W.; Luo, W.; Wang, J.; Li, K.; Yeung, N.; Kite, S. Assessing the $\mathrm{CO}_{2}$ reduction target gap and sustainability for bridges in China by 2040. Renew. Sustain. Energy Rev. 2022, 154, 111811. [CrossRef]

186. Meng, M.; Qu, D. Understanding the green energy efficiencies of provinces in China: A Super-SBM and GML analysis. Energy 2022, 239, 121912. [CrossRef]

187. Yamaguchi, Y.; Kim, B.; Kitamura, T.; Akizawa, K.; Chen, H.; Shimoda, Y. Building stock energy modeling considering building system composition and long-term change for climate change mitigation of commercial building stocks. Appl. Energy 2022, 306, 117907. [CrossRef]

188. Al Shawa, B. The ability of Building Stock Energy Models (BSEMs) to facilitate the sector's climate change target in the face of socioeconomic uncertainties: A review. Energy Build. 2022, 254, 111634. [CrossRef]

189. Lin, J.; Zhong, X.; Wang, J.; Huang, Y.; Bai, X.; Wang, X.; Shah, N.; Xie, S.; Zhao, Y. Relative optimization potential: A novel perspective to address trade-off challenges in urban energy system planning. Appl. Energy 2021, 304, 117741. [CrossRef]

190. Zhang, S.; Wang, K.; Xu, W.; Iyer-Raniga, U.; Athienitis, A.; Ge, H.; Cho, D.w.; Feng, W.; Okumiya, M.; Yoon, G.; et al. Policy recommendations for the zero energy building promotion towards carbon neutral in Asia-Pacific Region. Energy Policy 2021, 159, 112661. [CrossRef]

191. Su, C.; Urban, F. Carbon Neutral China by 2060: The Role of Clean Heating Systems. Energies 2021, 14, 7461. [CrossRef]

192. Zhong, X.; Hu, M.; Deetman, S.; Steubing, B.; Lin, H.X.; Hernandez, G.A.; Harpprecht, C.; Zhang, C.; Tukker, A.; Behrens, P. Global greenhouse gas emissions from residential and commercial building materials and mitigation strategies to 2060. Nat. Commun. 2021, 12, 6126. [CrossRef] [PubMed]

193. Fan, G.J.; Zhao, Y.J.; Zhang, X.D.; Li, Y.L.; Chen, H. Research on Minimum Miscible Pressure Between Crude Oil and Supercritical Carbon Dioxide System in Ultra-Low Permeability Reservoir by the Long-Slim-Tube Experiment Method. Front. Earth Sci. 2021, 9, 9. [CrossRef]

194. Jia, J.J.; Xu, J.H. Estimating residential electricity demand's response to price policy and income dynamics in China. Energy Effic. 2021, 14, 23. [CrossRef]

195. Liu, J.L.; Yin, M.J.; Xia-Hou, Q.R.; Wang, K.; Zou, J. Comparison of sectoral low-carbon transition pathways in China under the nationally determined contribution and 2 degrees $C$ targets. Renew. Sust. Energ. Rev. 2021, 149, 13. [CrossRef]

196. Wang, L.; Lee, E.W.M.; Hussian, S.A.; Yuen, A.C.Y.; Feng, W. Quantitative impact analysis of driving factors on annual residential building energy end-use combining machine learning and stochastic methods. Appl. Energy 2021, 299, 117303. [CrossRef] 
197. Zhang, S.-C.; Yang, X.-Y.; Xu, W.; Fu, Y.-J. Contribution of nearly-zero energy buildings standards enforcement to achieve carbon neutral in urban area by 2060. Adv. Clim. Change Res. 2021, 12, 734-743. [CrossRef]

198. Chi, F.a.; Wang, R.; Wang, Y. Integration of passive double-heating and double-cooling system into residential buildings (China) for energy saving. Sol. Energy 2021, 225, 1026-1047. [CrossRef]

199. Liu, Q.C.; Liu, L.T.; Liu, X.J.; Li, S.G.; Liu, G. Building stock dynamics and the impact of construction bubble and bust on employment in China. J. Ind. Ecol. 2021, 25, 1631-1643. [CrossRef]

200. Yang, X.Y.; Zhang, S.C.; Wang, K. Quantitative study of life cycle carbon emissions from 7 timber buildings in China. Int. J. Life Cycle Assess. 2021, 26, 1721-1734. [CrossRef]

201. Yue, H.; Worrell, E.; Crijns-Graus, W.; Liu, W.; Zhang, S.H. Saving energy in China's industry with a focus on electricity: A review of opportunities, potentials and environmental benefits. Energy Effic. 2021, 14, 28. [CrossRef]

202. Vand, B.; Ruusu, R.; Hasan, A.; Manrique Delgado, B. Optimal management of energy sharing in a community of buildings using a model predictive control. Energy Convers. Manag. 2021, 239, 114178. [CrossRef]

203. Jiang, J.J.; Ye, B.; Shao, S.; Zhou, N.; Wang, D.S.; Zeng, Z.Z.; Liu, J.G. Two-Tier Synergic Governance of Greenhouse Gas Emissions and Air Pollution in China's Megacity, Shenzhen: Impact Evaluation and Policy Implication. Environ. Sci. Technol. 2021, 55, 7225-7236. [CrossRef] [PubMed]

204. Tong, H.; Li, H.B.; Zhou, Z.N.; Cidanpuchi; Wang, F.C.; Liu, W. Strategies for optimizing the luminescence and stability of copper iodide organic-inorganic hybrid structures. New J. Chem. 2021, 45, 10989-10996. [CrossRef]

205. Gou, S.W.; Li, H.; Li, J.Y.; Zhao, Y. Effective means to alleviate the greenhouse effect: Case study of history match simulations on a brief $\mathrm{CO}_{2}$ injection into less-deep low-rank coal seams. Arab. J. Geosci. 2021, 14, 18. [CrossRef]

206. Zhao, Y.; Fan, G.; Li, Y.; Zhang, X.; Chen, H.; Sun, H. Research for reducing minimum miscible pressure of crude oil and carbon dioxide and miscible flooding experiment by injecting citric acid isopentyl ester. Arab. J. Chem. 2020, 13, 9207-9215. [CrossRef]

207. Yue, H.; Worrell, E.; Crijns-Graus, W. Impacts of regional industrial electricity savings on the development of future coal capacity per electricity grid and related air pollution emissions-A case study for China. Appl. Energy 2021, 282, 116241. [CrossRef] 